\title{
Antecedents and Consequences of Service Climate in Boundary-Spanning Self-Managing Service Teams
}

Citation for published version (APA):

de Jong, A., de Ruyter, J. C., \& Lemmink, J. G. A. M. (2004). Antecedents and Consequences of Service Climate in Boundary-Spanning Self-Managing Service Teams. Journal of Marketing, 68(2), 18-35.

https://doi.org/10.1509/jmkg.68.2.18.27790

Document status and date:

Published: 01/01/2004

DOI:

10.1509/jmkg.68.2.18.27790

Document Version:

Publisher's PDF, also known as Version of record

\section{Please check the document version of this publication:}

- A submitted manuscript is the version of the article upon submission and before peer-review. There can be important differences between the submitted version and the official published version of record.

People interested in the research are advised to contact the author for the final version of the publication, or visit the DOI to the publisher's website.

- The final author version and the galley proof are versions of the publication after peer review.

- The final published version features the final layout of the paper including the volume, issue and page numbers.

Link to publication

\footnotetext{
General rights rights.

- You may freely distribute the URL identifying the publication in the public portal. please follow below link for the End User Agreement:

www.umlib.nl/taverne-license

Take down policy

If you believe that this document breaches copyright please contact us at:

repository@maastrichtuniversity.nl

providing details and we will investigate your claim.
}

Copyright and moral rights for the publications made accessible in the public portal are retained by the authors and/or other copyright owners and it is a condition of accessing publications that users recognise and abide by the legal requirements associated with these

- Users may download and print one copy of any publication from the public portal for the purpose of private study or research.

- You may not further distribute the material or use it for any profit-making activity or commercial gain

If the publication is distributed under the terms of Article $25 \mathrm{fa}$ of the Dutch Copyright Act, indicated by the "Taverne" license above, 


\section{Antecedents and Consequences of the Service Climate in Boundary-Spanning Self-Managing Service Teams}

In this article, the authors examine antecedents and consequences of the service climate in boundary-spanning self-managing teams (SMTs) that deliver financial services. Using data from members of 61 SMTs and their customers, the authors show a differential impact of the SMT service climate on various marketing performance measures. Furthermore, they obtain support for independent group-level effects of intrateam support and team member flexibility on employee perceptions of the SMT service climate. Both effects are persistent over time and demonstrate that collective perceptions in the SMT have incremental value in the explanation of the service climate.

$\mathbf{R}$ esearch on boundary-spanning service employees has shown that delegation of authority to the front line allows for greater flexibility and adaptability in the performance of service activities through better problem solving, closer employee cooperation, and more efficient knowledge transfer (Hartline and Ferrell 1996). In apparent recognition of this, some companies have organized their front-office operations around self-managing teams (SMTs), or groups of interdependent employees that have the collective authority and responsibility to manage and perform relatively whole tasks. Team members are typically crosstrained in various skills, including developing work routines, planning, and monitoring team performance (Yeatts and Hyten 1998). Companies such as Charles Schwab, Taco Bell, Prudential, Pacific Bell (now part of SBC Communications), CIGNA, Welch Foods, and Xerox have implemented boundary-spanning SMTs (Batt 1999; Cameron and Boise 1995; Wageman 1997).

It has been argued that self-management is an excellent mechanism for improving the performance of the employee-customer interface (Gilson, Shalley, and Blum 2001). However, this claim is not substantiated by the empirical evidence. Whereas Batt (1999) shows that frontoffice service SMTs perform significantly better in terms of service quality and sales volume than do teams under management control, Chaston (1998) reports an adverse impact

Ad de Jong is a postdoctoral researcher (e-mail: a.dejong@mw. unimaas.nl), Ko de Ruyter is Professor of International Service Research and Director of the Maastricht Academic Center for Research in Services (e-mail: k.deruyter@mw.unimaas.nl), and Jos Lemmink is Professor of Marketing and Market Research and Department Chair (e-mail: j.lemmink@ms.unimaas.nl), Department of Marketing, Faculty of Economics and Business Administration, Maastricht University, The Netherlands. The authors thank Richard Feinberg, Roberta Levy, Christine Moorman, Tor Wallin Andreassen, Pratibha Dabholkar, and the four anonymous JM reviewers for their valuable comments on previous drafts of this article. on service quality and productivity. Whereas Wageman (1997, p. 32) states that the performance of field-service SMTs at Xerox is "critical to the company's ultimate success," other reports from the business press contest the validity of this assumption (e.g., Zemke 1993). Empirical inconsistencies, conflicting anecdotes, and a lack of theoretical development regarding SMTs in service settings emphasize the need for research that addresses four important theoretical and empirical issues that have been unresolved in previous studies.

First, the research to date has virtually ignored the development of a mediating construct to account convincingly for the apparent inconsistencies in SMT performance. At the firm level, Schneider, White, and Paul (1998) demonstrate that a service climate is a key mediating factor in the prediction of marketing performance. Accordingly, we advance a construct of the SMT service climate that is proximal to perceptions of work-group practices to explain performance variability among teams.

Second, previous research on customer-contact SMTs has focused predominantly on processes within the team (e.g., Cohen, Chang, and Ledford 1997). However, as Hackman (1992) argues, teams do not operate in isolation. Therefore, climate perceptions may also be the result of organizational context characteristics. We develop a conceptual framework that takes into account both team- and companyrelated predictors of the SMT service climate.

A third issue that has not been explored is whether climate-defining team characteristics have an impact at the work-group level that is beyond the perception of individual employees. Each SMT may develop a unique set of shared perceptions of desirable behavior (e.g., the level of support to other team members), and between-group differences may be contingent on these perceptions (Mathieu and Kohler 1990). Therefore, we examine whether group-level aggregations of team member perceptions incrementally determine employee perceptions of the SMT service cli- 
mate. The group-level effects may be contingent on the type of service delivery. Stewart and Barrick (2000) demonstrate that task type moderates variability in the magnitude of reported predictor-criterion relationships in explaining manufacturing SMT performance. We extend this finding by considering distinct types of service delivery in our analysis of group-level antecedents and consequences of the SMT service climate.

Fourth, the impact of boundary-spanning teams on business performance measures (Batt 2002) is unknown. Part of the gap in the knowledge about SMT effectiveness stems from the complexity in considering various types of performance measures (e.g., customer evaluations versus productivity measures) across different types of service delivery (Batt 2002). Another reason is that extant studies may not have been able to provide definitive conclusions on frontline SMT effectiveness because they employed cross-sectional data on relationships that might have needed to be separated in time (Griffin 1991). Therefore, we examine the lagged effects of the SMT service climate on customer perceived quality, share of customer, and sales productivity for two types of service delivery.

The increasing importance and ubiquity of boundaryspanning SMTs, despite inconsistent and sometimes contradictory findings, create the need for more definitive research that describes and defines the nature and scope of SMTs and their possible effects. We propose four additions to SMT research and test the theoretical and empirical advantages and implications of these additions.

\section{Development of a Conceptual Framework}

\section{SMT Service Climate}

Although various employee-based measures (e.g., job satisfaction) have been advanced as drivers of service performance, it also has been argued that service climate has superior predictive power (Schneider, Wheeler, and Cox 1992). We extend previous research by adopting a team-level focus on service climate. Our conceptual point of departure for developing several definitional assumptions is Katz and Kahn's (1978) description of climate being the result of a distinct pattern of individual team members' collective beliefs developed through members' interaction with their social environments. First, this description theoretically relates climate to antecedent variables in the organizational and team contexts (Lindell and Brandt 2000). Second, Katz and Kahn (1978) posit that perceptions of climate are essentially a property of the individual member that can be aggregated to reflect a group-level construct (see James and James 1989). Third, as climate is related to various environments, different climates may exist for organizational goals and structural levels. Proximal measures that conceptualize climate in terms of both goals (e.g., customer service) and levels (e.g., the team) produce strong relationships with targeted performance parameters (Tesluk et al. 1995). Finally, because climate involves the construction of shared meaning through the process of interaction, the process is dynamic and in line with Hackman's (1987) process criterion of effectiveness, which relates to team members' effort, knowledge, skill, and performance in achieving team goals. Thus, we define SMT service climate as the collective beliefs of SMT members on effort, knowledge, skills, and performance with regard to effective service delivery.

\section{Antecedents of SMT Service Climate: An Individual-Level Perspective}

Our framework, which relates SMT service climate to its antecedents, has two distinct conceptual roots: (1) Hackman's (1987) normative model of team effectiveness, which distinguishes intra- and extrateam factors, and (2) the involvement approach (Bowen and Lawler 1992), according to which employees are given the authority and resources to coordinate, plan, and control the service delivery process. Three main characteristics that differentiate service SMTs from other traditional work groups govern our choice of predictor variables: (1) higher levels of autonomy, (2) functional flexibility, and (3) interdependency within and between teams (Campion, Medsker, and Higgs 1993). In general, SMTs are designed with a certain degree of rolerelated diversity (Yeatts and Hyten 1998). Researchers have posited that perceptions of collective phenomena (i.e., service climate) represent cognitive interpretations of proximal structures and processes based on a person's experience, values, knowledge, and expertise (Brown and Leigh 1996). Thus, members of the same SMT may have different perceptions of the SMT service climate defining antecedents. Prior research on work groups has demonstrated that withingroup perceptual deviation reflects systematic (not random) variance that may represent differential cognitive appraisals of the team environment (Van Yperen and Snijders 2000). Thus, we postulate predictor-criterion relationships at the individual level.

Hackman (1987) posits that a supportive organizational context is a major determinant of group effectiveness. A central component of the involvement approach is empowerment, which refers to the notion that service employees must be given a certain degree of autonomy and be able to perform job-related activities with skill (Hartline and Ferrell 1996). Recent research on production teams demonstrates that senior management's lack of tolerance for selfmanagement may be an important barrier to SMT effectiveness (Balkema and Molleman 1999). Furthermore, in the case of boundary-spanning SMTs, it has been consistently argued that perceived autonomy is critical to the attitude and behavior of customer-contact personnel (Batt 1999; Van Mierlo et al. 2001; Wageman 1995). Thus:

\section{$\mathrm{H}_{1}$ : Tolerance for self-management positively affects employ-} ees' perceptions of the SMT service climate.

In addition, SMT members need to be able to use delegated authority optimally; this ability has been associated with several synergistic processes in teams (Hackman 1987). The SMT members should be capable of performing various team tasks, whether operational, managerial, or administrative (Spreitzer, Cohen, and Ledford 1999). As the spectrum of SMTs' tasks grows, job assignments rapidly evolve, SMTs need to become highly interdependent, and there is a need for flexible and multiskilled members (Batt 
1999; Sundstrom, de Meuse, and Futrell 1990). Recent research (Marks, Mathieu, and Zaccaro 2001; Mathieu et al. 2000) has demonstrated that the ability to perform interrole behaviors facilitates attainment of team goals. We hypothesize that perceptions of team member flexibility form another relevant foundation for the establishment of service climate:

$\mathrm{H}_{2}$ : Flexibility of team members positively affects employees' perceptions of the SMT service climate.

The literature on employee involvement has demonstrated that coworker involvement reduces perceptions of boundary-spanner role stress and increases service performance (Bettencourt and Brown 1997). The implication is that when service employees experience peer-based learning and coworkers' service-driven attitude, they will be motivated to carry over this attitude to their customer encounters. Frequently, cooperative interaction within and between SMTs is required to address customer service requests successfully and to create a service-oriented work environment (Horwitz and Neville 1996). The services marketing literature posits that mutual support among employees is essential to the implementation of service-quality improvements (Berry, Parasuraman, and Zeithaml 1994). Batt (1999) has shown that collaborative endeavors are a key success factor of SMT effectiveness in boundary positions. Conceptually, we distinguish between inter- and intrateam support. Interteam support refers to team member perceptions of the internal service and communication between teams and other units in the organization, whereas intrateam support pertains to team members' willingness to offer help and to deliver service to other members of the group in order to attain work-group goals (Campion, Medsker, and Higgs 1993). We hypothesize the following:

$\mathrm{H}_{3}$ : Employee perceptions of the SMT service climate are positively affected by (a) interteam support and (b) intrateam support.

Although some researchers claim that the individual perspective constitutes the only proper unit of analysis, others argue that the study of group phenomena can be analyzed in a meaningful way only at the group level (Lindell and Brandt 2000). Therefore, in the next section, we discuss the conceptualization of the aforementioned predictor variables at the group level.

\section{Antecedents of SMT Service Climate: A Group- Level Perspective}

It has been advanced that by evoking the notion of climate, each team can develop a unique set of norms and mental models regarding desirable behavior (e.g., the level of support to other team members), thus reflecting between-group differences (Mathieu and Kohler 1990). Studies on shared mental models (Mathieu et al. 2000) and transactive memory in teams (Liang, Moreland, and Argote 1995) demonstrate that team members develop shared beliefs about their team that instigate team members to develop interrelated knowledge and norm structures to facilitate group processes. Lindell and Brandt (2000, p. 332) state that shared beliefs reflect that individual members "are socialized to act in similar ways, are exposed to similar features within contexts, and come to share their interpretations with others in the setting." Beliefs are conceptually distinct from constructs that exist at the group level only (e.g., team size) (Gully et al. 2002). Aggregate-level constructs reflect psychosocial traits that are not captured by the individual-level measurement (Hackman 1992). These constructs may differentially influence individual members' perceptions of the SMT service climate. Group-level constructs strongly reflect the basic assumption of synergistic processes within the SMT (Hackman 1987). Poole and McPhee (1983, p. 213) view sources of work-unit climate as collective attitudes that are "continually produced and reproduced by members' interactions." Particularly in service SMTs, there is a relatively high level of interdependence and interactions (Batt 1999), in which shared perceptions, unique to the work unit, are formed.

To better understand the similarities and differences inherent in multiple-level constructs, scholars have used the typology of elemental composition (Bliese 2000; Chan 1998). Elemental composition takes place when a higherlevel construct consists of collective lower-level measures. The composition model for the SMT antecedents in our study is the direct consensus model, which characterizes climate-defining antecedents as properties of the individual team member. At the same time, when there is consensus between individual perceptions (e.g., on intrateam support), the aggregate composes a construct at the work-group level that represents shared perceptions of a collective belief. Prior research on teams' withdrawal behavior (absenteeism and lateness) in boundary-spanning service settings provides evidence of the influence of group-level predictors on individual employee behavior beyond individual-level antecedents. Mathieu and Kohler (1990) and Blau (1995) report significant effects of aggregated group-level variables on individual employee behavior in auto repair, hospital, and banking service teams. Their results seem to support Bryk and Raudenbush's (1992) contention that group-level aggregations of contextual properties represent a distinct perspective that may not be captured by individual-level measures. Therefore, we hypothesize the following:

$\mathrm{H}_{4}$ : At the group level of analysis, the positive effects of (a) tolerance for self-management, (b) team member flexibility, (c) interteam support, and (d) intrateam support account for a significant amount of additional variance in individual employees' perceptions of the SMT service climate.

\section{Antecedent-SMT Service Climate Relationships Across Service Types}

Positive linear relationships between SMT characteristics and member-related outcomes (e.g., employee satisfaction, organizational commitment) within and across various frontline service settings have not yielded a consistent pattern (Batt 1999; Cohen, Chang, and Ledford 1997; Gilson, Shalley, and Blum 2001; Wageman 1997). Variability in the magnitude of reported predictor-criterion relationships may indicate the presence of moderator variables, such as task characteristics. In a manufacturing setting, Stewart and Barrick (2000) show that SMTs that are responsible for routine tasks are less likely to be affected by flexibility and interdependency than are SMTs that perform nonroutine activities. 
Recent research by Marks and colleagues (2002) demonstrates that the development of shared beliefs regarding team processes fosters coordinated task behavior and the ability to adapt dynamically in uncertain environments. Particularly in the case of nonroutine tasks, norm congruence and shared understanding on how to function as an SMT affect climate perceptions. Because services have also been classified in terms of a routine-nonroutine continuum (Davis 1999), we expect service type to moderate the impact of group-level predictor variables. We posit the following:

$\mathrm{H}_{5}$ : Service type moderates the positive effects of (a) tolerance for self-management, (b) team member flexibility, (c) interteam support, and (d) intrateam support on employees' perceptions of the SMT service climate, such that effects are significantly stronger at the group level for nonroutine services than for routine ones.

\section{Consequences of SMT Service Climate}

There is ample evidence that employee perceptions of service climate at the firm level have a positive influence on customer perceptions of service quality (Schneider et al. 1996; Schneider and Bowen 1985; Schneider, White, and Paul 1998). In addition to psychological outcome parameters, it has been argued that the behavioral outcome "share of customer," or the number of services purchased from a specific service provider, is a key marketing-performance indicator (Babin and Attaway 2000). The overall premise is that the impact of policies and practices aimed to serve the customer should also be observable in customer behavior, because both perceived service quality and purchase behavior are closely related and should be evaluated simultaneously when pursuing profitability (Soteriou and Zenios 1999). Service firms may also focus on productivity as a performance parameter, specifically on quantifiable behavioral standards of employee behavior, such as volume of services sold (Singh 2000). However, recent evidence suggests that, especially in the area of services, firms should make trade-offs between establishing a focus on delivering quality services and sales ratios per employee (Anderson, Fornell, and Rust 1997; Singh 2000). Thus, we expect that a strong SMT service climate with an emphasis on providing highstandard services will result in decreased productivity. It has been suggested in both the service marketing and the team literature that inconsistencies in performance assessment are contingent on the time frame used in the analysis (Griffin 1991). Empirical evidence from the services marketing literature shows that customers' assessments of service quality are relatively constant and subject to slow change (Bolton and Drew 1991). Moreover, Bernhardt, Donthu, and Kennett (2000) argue that the true impact of service changes in terms of observable customer behavior (e.g., actual services purchased) can be assessed only longitudinally. Finally, Griffin (1991) reports a delay between the implementation of frontline service SMTs and performance improvements. Therefore, we propose the following:

\footnotetext{
$\mathrm{H}_{6}$ : At the group level of analysis, SMT service climate at T1 positively affects (a) customer perceived service quality at $\mathrm{T} 2$ and (b) share of customer at T2.

$\mathrm{H}_{7}$ : At the group level of analysis, SMT service climate at T1 negatively affects sales productivity at $\mathrm{T} 2$.
}

\section{Assessment of Consequences Across Service Types}

Finally, we posit that the impact of SMT service climate on the aforementioned parameters may depend on the type of service. Nonroutine service delivery frequently involves dealing with complex problems and equivocal situations that may benefit from an extended dialogue within the team and between team members and customers. We expect that a climate that fosters service excellence is more influential in such circumstances:

\section{$\mathrm{H}_{8}$ : At the group level of analysis, service type moderates the positive effects of SMT service climate at T1 (a) on cus- tomer perceived service quality at T2 and (b) on share of customer at T2 and moderates (c) the negative effect on sales productivity at $\mathrm{T} 2$, such that effects are significantly stronger at the group level for nonroutine services than for routine ones.}

Figure 1 reflects our conceptual framework and provides an overview of the issues discussed thus far.

\section{Empirical Study}

\section{Research Setting}

Members of a large Dutch bank's SMTs and customers were surveyed. The bank employs approximately 48,000 people and has 424 branch offices. It operates in both business and consumer markets and promotes service excellence as a key to marketing success. In each branch, separate routine and nonroutine SMTs are responsible for servicing consumers, and other SMTs deal with business customers or are responsible for internal operations (e.g., human resources management, general and technical services). In our study, we focused on SMTs that deliver consumer services. Each branch offers a wide range of services to consumers: nonroutine, knowledge-intensive services (e.g., investment consulting, trust services, estate planning) and routine, transaction-intensive services (e.g., checks and deposits, currency exchanges, credit application accounts). At each branch, separate front-office SMTs are responsible for the different service types (e.g., financial versus client advisory teams). The bank considered implementation of team-based self-management an important organizational change process. Therefore, the practical rationale for conducting our study at the initiation phase (T1) and seven months later (T2) was to evaluate the central role of SMT service climate and examine its impact on service performance.

\section{Sampling and Surveying}

Of 848 boundary-spanning SMTs, we randomly selected a sample of 100 . Unwillingness to cooperate and the lack of sales productivity and customer data resulted in a total set of 61 SMTs. We collected data from individual employees organized in SMTs using self-report questionnaires (at T1 and at T2) and from their customers (at T2) using mail questionnaires. For the employee survey, we invited all members of the SMT to participate. In total, 939 questionnaires were returned at $\mathrm{T} 1(76.4 \%)$ and 730 questionnaires at $\mathrm{T} 2$ $(62.1 \%)$. For the customer survey, we drew a random sample of 150 customers per SMT at T2. In total, 1884 ques- 
FIGURE 1

Conceptual Framework

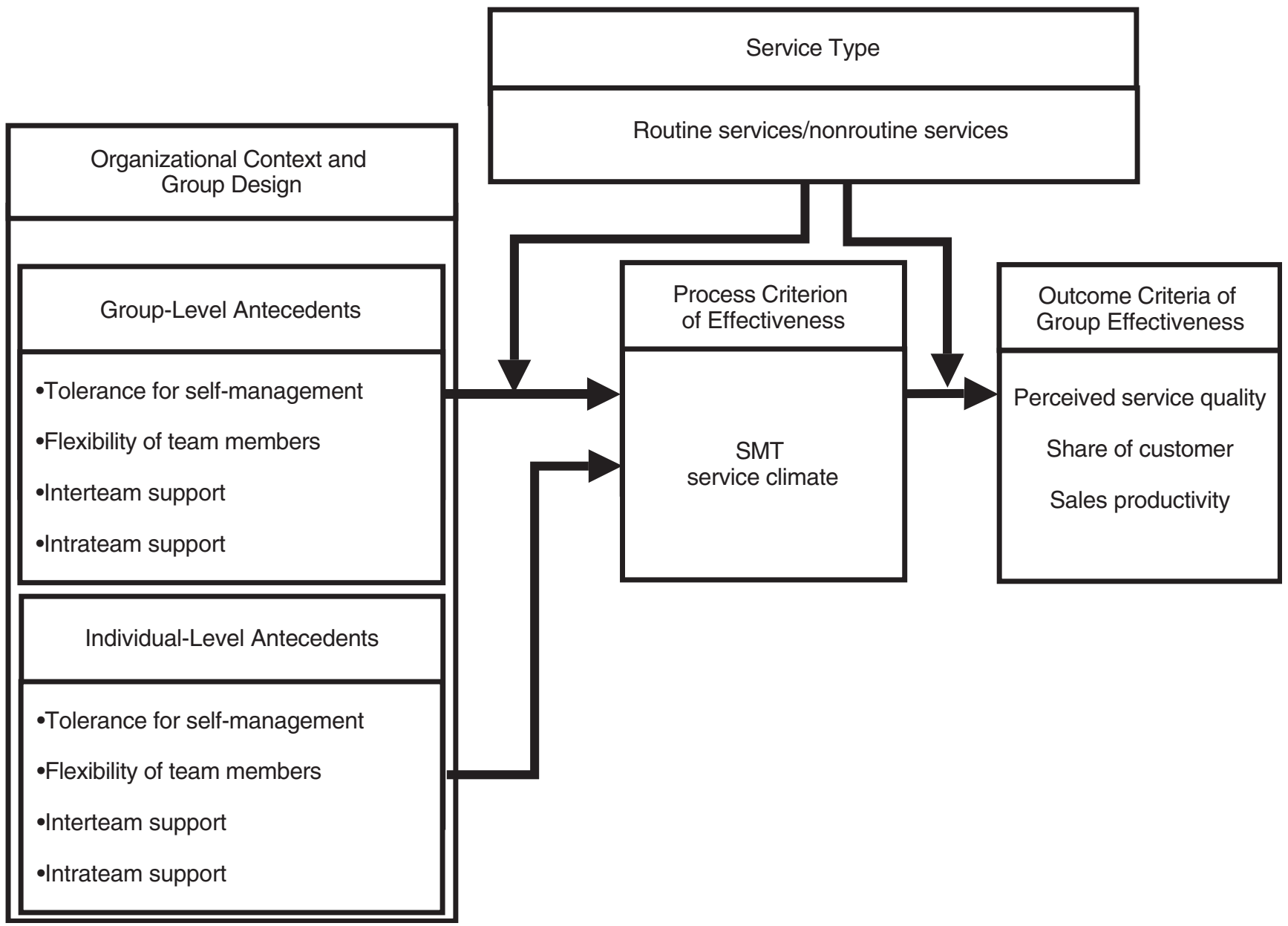

tionnaires were returned (20.8\%). For the employee survey, we used 568 questionnaires from 36 nonroutine service teams ( 316 from 36 teams at $\mathrm{T} 1$ and 252 from 33 teams at T2) and 917 questionnaires from 25 routine service teams ( 509 from 25 teams at T1 and 408 from 23 teams at T2) for further analysis. For the customer survey, we analyzed 957 questionnaires of customers of 36 nonroutine service teams and 577 questionnaires of 25 routine service teams. With respect to the customer survey, we acquired the following sample profile: Most respondents were male $(63.8 \%)$ and older than 44 years of age $(58.5 \%)$. Virtually all respondents had a long-lasting relationship with the bank $(93.1 \%$ more than five years) and half of them visited the bank at least once a month (49.8\%). Detailed background data on participants at $\mathrm{T} 1$ as well as functional areas and responsibilities of the SMTs are included in Table 1.

\section{Measurement Issues}

The assessment of the SMT service climate involved items we specifically developed for this study; in-depth interviews with frontline employees; and scales developed by Schneider, Wheeler, and Cox (1992) and Peccei and Rosenthal (1997). We based the operationalization of tolerance for self-management (seven items) largely on the tolerance-offreedom instrument of the Leader Behavior Description Questionnaire, which assesses the degree of autonomy given to employees to manage their task responsibilities themselves (Cook et al. 1981). We measured team member flexibility and inter- and intrateam support with scales developed by Campion, Medsker, and Higgs (1993). We measured all scale items for the employee survey on a seven-point scale that ranged from 1 = "strongly disagree" to $7=$ "strongly agree." A qualified translator translated items into Dutch using the double back-translation procedure (Brislin 1980).

We employed two techniques to test the factor structure and the item loadings of the data collected at T1. We initially examined coefficient alphas and the factor structure (using principal components analysis) for all the scale items simultaneously. We achieved a five-factor structure in which items loaded on a priori dimensions. In addition, we conducted a confirmatory factor analysis (CFA) using LISREL to assess the measurement properties of the items. The fit indexes of the proposed factor model, construct reliabilities of the scales, and confirmatory factor loadings with t-values for each item are reported in Table 2. The indexes of the pro- 
TABLE 1

Descriptors of SMTs at T1

\begin{tabular}{|c|c|c|c|c|}
\hline & \multicolumn{2}{|c|}{$\begin{array}{l}\text { Employees of SMTs in } \\
\text { Nonroutine Services }(N=316)\end{array}$} & \multicolumn{2}{|c|}{$\begin{array}{c}\text { Employees of SMTs in } \\
\text { Routine Services }(N=509)\end{array}$} \\
\hline & Frequency & Percentage & Frequency & Percentage \\
\hline \multicolumn{5}{|l|}{ Sex } \\
\hline Male & 187 & 59.2 & 86 & 16.9 \\
\hline Female & 129 & 40.8 & 423 & 83.1 \\
\hline \multicolumn{5}{|l|}{ Age (Years) } \\
\hline Younger than 40 & 149 & 47.2 & 303 & 59.5 \\
\hline Older than 40 & 167 & 52.8 & 206 & 40.5 \\
\hline \multicolumn{5}{|l|}{ Education Level } \\
\hline Secondary & 59 & 18.7 & 131 & 25.7 \\
\hline Tertiary & 257 & 81.3 & 378 & 74.3 \\
\hline \multicolumn{5}{|c|}{ Organizational Tenure (Years) } \\
\hline Less than 5 & 123 & 38.9 & 242 & 47.5 \\
\hline More than 5 & 193 & 61.1 & 267 & 52.5 \\
\hline \multicolumn{5}{|c|}{ Team Experience (Years) } \\
\hline Less than 2 & 146 & 46.2 & 166 & 32.6 \\
\hline More than 2 & 170 & 53.8 & 343 & 67.4 \\
\hline \multicolumn{5}{|l|}{ Job } \\
\hline Full time & 217 & 68.7 & 217 & 42.6 \\
\hline \multirow{3}{*}{ Part time } & 99 & 31.3 & 292 & 57.4 \\
\hline & \multicolumn{4}{|c|}{ SMT Characteristics } \\
\hline & \multicolumn{2}{|c|}{ Nonroutine Services } & \multicolumn{2}{|c|}{ Routine Services } \\
\hline Team size (mean [s.d.]) & \multicolumn{2}{|c|}{$13.98(5.85)$} & \multicolumn{2}{|c|}{$36.76(12.70)$} \\
\hline Functional areas & \multicolumn{2}{|c|}{$\begin{array}{c}\text { General financial advisers } \\
\text { Mortgage advisers } \\
\text { Portfolio advisers } \\
\text { Financial planners } \\
\text { Insurance advisers } \\
\text { Clerical staff } \\
\text { Risk analysts }\end{array}$} & \multicolumn{2}{|c|}{$\begin{array}{c}\text { Client services employees } \\
\text { Cashiers } \\
\text { Receptionists } \\
\text { Travel services } \\
\text { Clerical staff } \\
\text { Customer services (customer } \\
\text { complaint management) }\end{array}$} \\
\hline Responsibilities & \multicolumn{4}{|c|}{$\begin{array}{c}\text { Developing new work routines } \\
\text { Monitoring member and team performance } \\
\text { Service recovery } \\
\text { Internal and external coordination }\end{array}$} \\
\hline
\end{tabular}

Notes: In essence, the responsibilities of the SMTs do not differ between routine and nonroutine services.

posed factor model provide a good fit and show unidimensionality of the scales. ${ }^{1}$ We tested construct reliabilities of

\footnotetext{
${ }^{1}$ To assess the construct validity of our focal variable, we conducted an additional CFA in which we included both SMT service climate and its conceptual counterpart "overall service climate" (Schneider, White, and Paul 1998). The results $\left(\chi^{2}=236.74,43\right.$ d.f.; goodness-of-fit index $=.97$; adjusted goodness-of-fit index $=$ .95 ; root mean square error of approximation $=.057$; normed fit index $=.98$; and comparative fit index $=.98$ ) indicate the unidimensionality of both constructs. To determine discriminant validity, we used a chi-square difference test (1 d.f.) to test for unity between the constructs. The test showed significance at $p<.05$.
}

the scales by means of Cronbach's alpha. Coefficients of all measures were greater than .65 , which implies that reliability is acceptable (Nunnally and Bernstein 1994).

Next, we examined within-method convergent validity by investigating the significance and magnitude of the item loadings. All items loaded significantly on their respective construct (minimum t-value $=12.50$ ), and $95 \%$ of all items had a standardized loading of at least .50. In addition, we evaluated discriminant validity. All chi-square difference tests ( 1 degree of freedom [d.f.]) were significant $(p<.05)$, which indicates that all pairs of constructs correlated at less than one. Subsequently, we included as control variables the 
TABLE 2

Measures and Measurement Criteria

Employee Dataa

SMT Service Climate ( $n=6 ; \alpha=.86$ at T1; $\alpha=.88$ at T2)

1. Our team is continually working to improve the quality of service we provide to our customers.

2. Our team has specific ideas about how to improve the quality of service we provide to customers.

3. Our team often makes suggestions about how to improve the service quality of our organization.

4. In our team we put a lot of effort in attempting to satisfy customer expectations.

5. No matter how we feel, we always put ourselves out for every customer we serve.

6. Within our team, employees often go out of their way to help customers.

$\begin{array}{lll}5.81 & .78 & 25.54 \\ 5.32 & .67 & 20.94 \\ & & \\ 5.01 & .51 & 14.85 \\ 5.68 & .83 & 28.22 \\ 5.45 & .71 & 22.55 \\ 5.30 & .73 & 23.23 \\ & & \\ 5.27 & .71 & 22.50 \\ 6.09 & .64 & 19.48 \\ 5.83 & .81 & 27.28 \\ 5.54 & .86 & 29.94 \\ 5.25 & .76 & 24.73 \\ 5.22 & .72 & 23.09\end{array}$

Tolerance for Self-Management $(n=6 ; \alpha=.89$ at T1; $\alpha=.90$ at T2)

1. In our team we are permitted to use our own judgment in solving problems.

2. In our team we are encouraged to take initiative.

3. Our team is allowed a high degree of initiative.

4. In our team we are allowed complete freedom in our work.

5. In our team we are allowed to do our work the way we think best.

6. As a team we are able to handle all tasks assigned to us.

Flexibility of Team Members $(n=4 ; \alpha=.68$ at T1; $\alpha=.74$ at T2)

1. In our team it is easy to stand in for each other.

2. Most team members know each other's tasks.

3. I have much confidence that my team members would be able to take over my activities.

4. Exchanging team roles and responsibilities causes few problems.
5.47

5.97

5.69

4.68

4.44

4.93

4.64

3.46

4.66

4.32

4.71

5.06

5.18

4.98

5.04
66

.58

.66

.48

.55

.56

.75

.53

.54

.85

.75

18.03

15.49

17.94

12.50

16.03

16.56

23.75

15.28

15.80

28.56

24.09

Intrateam Support $(\mathrm{n}=4 ; \alpha=.66$ at $\mathrm{T} 1 ; \alpha=.68$ at T2)

1. In our team we help each other in serving the customer.

2. The mutual support of team members is highly valued.

3. Each team member is personally responsible for the assistance of other members in serving the customer.

4. In our team members need not formally be monitored with regard to the assistance of colleagues.
19.88

23.57

15.03

14.67
Item

Mean

Loading

t-Value

Measures

Customer Perceived Service Quality $(\mathrm{n}=8 ; \alpha=.92)$

1. The extent to which employees make clear appointments

2. Speed at which the promised information is provided

3. The friendliness and politeness of employees

4. The competence of the service by employees

5. The time taken by employees to serve you

6. The attention employees pay to you

7. The extent to which employees show empathy

8. The readiness of the employees to help you

\section{Customer Data}


TABLE 2

Continued

\begin{tabular}{|c|c|c|}
\hline Share of Customer & Nonroutine Services & Routine Services \\
\hline $\begin{array}{l}\text { Average customer usage rates (\%) } \\
\text { of the different services offered }\end{array}$ & $\begin{array}{c}\text { Mortgages, loans }(53.6 \%) \\
\text { Investment funds }(52.7 \%) \\
\text { Stocks }(43.9 \%) \\
\text { Insurance }(46.5 \%)\end{array}$ & $\begin{array}{c}\text { Checking account }(95.2 \%) \\
\text { Savings account }(79.1 \%) \\
\text { Electronic/telephone banking (30.3\%) } \\
\text { Currency exchange }(20.1 \%) \\
\text { Credit application accounts }(44.9 \%) \\
\text { Travel services }(18.7 \%)\end{array}$ \\
\hline
\end{tabular}

aThe CFA is based on employee data collected at T1.

Notes: All t-values are significant at $p<.05$. For employee data, fit indexes are $\chi^{2}=925.40,314$ d.f.; goodness-of-fit index (GFI) $=.92 ;$ adjusted goodness-of-fit index $(\mathrm{AGFI})=.91$; root mean square error of approximation $(\mathrm{RMSEA})=.049$; normed fit index $(\mathrm{NFI})=.90$; and comparative fit index $(\mathrm{CFI})=.93$. For customer data, fit indexes are $\chi^{2}=44.64,20$ d.f.; $\mathrm{GFI}=.99 ; \mathrm{AGFI}=.98 ; \mathrm{RMSEA}=.036 ; \mathrm{NFI}=.99$; and $\mathrm{CFI}=1.00$.

demographic variables education, organizational tenure, and age, as well as the work-group-design variables team size and percentage of front-office activities (i.e., direct customer-contact responsibilities) and nonroutine services, which is a dummy for service type (we coded nonroutine services as one and routine services as zero).

We measured two performance measures, customer perceived service quality and share of customer, using the customer survey. We based the scale for service quality on the SERVQUAL instrument developed by Parasuraman, Zeithaml, and Berry (1988). Our goal was to measure the quality of the services delivered by the service employees. Therefore, we restricted our measure to eight items that specifically addressed employee-related aspects of quality (Hartline and Ferrell 1996). We measured items on a fivepoint scale that ranged from $1=$ "very dissatisfied" to $5=$ "very satisfied." Principal components analysis showed construct validity (we extracted a single factor; loadings for all items were greater than .70). In addition, we conducted CFA to assess measurement properties. The fit indexes are reported in Table 2; they demonstrate unidimensionality, construct reliability, and convergent validity of the construct. To obtain a measure that we call "share of customer," customers were asked to indicate which types of services they used. The share-of-customer score for an SMT pertains to a group mean based on the average number of different service categories used by the customers of a specific team (see Table 2). Finally, we used data from the bank's internal database on the two service types (i.e., life insurance policies and investment portfolios for nonroutine services and number of checking and savings accounts for routine services). These parameters reflect the average amount of services sold per team member per year; we used them as a measure of sales productivity.

Means, standard deviations, and individual- and grouplevel correlations between the employee variables are presented in Table 3, which reveals that nonroutine service delivery is associated with higher-educated employees,

TABLE 3

Means, Standard Deviations, and Correlations of Employee Variables at T1

\begin{tabular}{|c|c|c|c|c|c|c|c|c|c|c|c|c|c|}
\hline Variables & Mean & (s.d.) & 1 & 2 & 3 & 4 & 5 & 6 & 7 & 8 & 9 & 10 & 11 \\
\hline 1. Education & 4.23 & $(1.60)^{a}$ & - & -.07 & .01 & $-.57^{\star \star \star}$ & $.35^{\star \star \star}$ & $.68^{\star \star \star}$ & .19 & $.42^{\star \star \star}$ & -.06 & -.07 & .01 \\
\hline 2. Tenure & 3.41 & $(1.67)^{b}$ & $-.28^{\star \star \star}$ & - & $.71^{\star \star \star}$ & -.18 & .19 & $.22^{\star}$ & -.08 & .01 & .00 & -.21 & -.10 \\
\hline 3. Age & 2.62 & $(.85)^{\mathrm{c}}$ & $-.16^{\star \star \star}$ & $.70^{\star \star \star}$ & - & -.15 & $.24^{*}$ & $.27^{\star \star}$ & .18 & .08 & .15 & $-.31^{\star \star}$ & -.01 \\
\hline 4. Team size & 20.44 & $(13.54)^{d}$ & - & - & - & - & $-.40^{\star \star \star}$ & $-.69^{\star \star \star}$ & -.06 & $-.34^{\star \star \star}$ & .09 & -.05 & .08 \\
\hline $\begin{array}{l}\text { 5. Front office (\%) } \\
\text { 6. Nonroutine }\end{array}$ & 47.03 & $(14.21)^{d}$ & - & - & - & - & - & $.46^{\star \star \star}$ & .19 & $.27^{\star \star}$ & -.04 & -.16 & .01 \\
\hline $\begin{array}{l}\text { services } \\
\text { 7. SMT service }\end{array}$ & .59 & $(.50)^{d}$ & - & - & - & - & - & - & .13 & $.34^{\star \star \star}$ & -.04 & -.15 & -.10 \\
\hline $\begin{array}{l}\text { climate } \\
\text { 8. Tolerance for }\end{array}$ & 5.43 & $(.82)$ & .02 & -.00 & .02 & - & - & - & - & $.56^{\star \star \star}$ & $.48^{\star \star \star}$ & .08 & $.62^{\star \star \star}$ \\
\hline $\begin{array}{l}\text { self-management } \\
\text { 9. Flexibility of }\end{array}$ & 5.54 & $(.89)$ & $.09^{\star \star}$ & .04 & .02 & 一 & - & - & $.37^{\star \star \star}$ & - & $.25^{\star}$ & .10 & $.34^{\star \star \star}$ \\
\hline members & 5.45 & $(.89)$ & -.00 & -.01 & .01 & - & - & - & $.38^{\star \star \star}$ & $.24^{\star \star \star}$ & - & .18 & $.53^{\star \star \star}$ \\
\hline 10. Interteam support & 4.45 & (.93) & $-.07^{\star \star}$ & $-.07^{\star \star}$ & $-.10^{\star \star \star}$ & - & - & - & $.28^{\star \star \star}$ & $.17^{\star \star \star}$ & $.26^{\star \star \star}$ & - & $.33^{\star \star}$ \\
\hline 11. Intrateam support & 5.07 & (.94) & -.03 & .03 & .06 & - & - & - & $.49^{\star \star \star}$ & $.32^{\star \star \star}$ & $.46^{\star \star \star}$ & $.33^{\star \star \star}$ & - \\
\hline
\end{tabular}

${ }^{*} p<.10$

${ }^{\star *} p<.05$.

${ }^{* * *} p<.001$.

aEducation consists of seven categories that include various forms of secondary and tertiary education.

bTenure consists of six categories that range from " $<1$ year" to " $>5$ years."

cAge consists of six categories that range from "<21 years old" to ">60 years old."

dMeans (s.d.) of team size, front-office work, and nonroutine services are based on the group averages.

Notes: $\mathrm{N}=825$ respondents of 61 groups. Individual-level correlations are in the lower triangle, and group-level correlations are in the upper triangle. Correlations in the upper triangle are the correlations between the group averages. 
smaller team sizes, higher percentages of front-office workers, and higher levels of tolerance for self-management than is routine service delivery. In Table 4, group-level means, standard deviations, and (partial) correlations of employee variables and external outcomes are presented. The SMT service climate appears to have the highest correlations with customers' perceived service quality. Furthermore, the correlations between antecedents and perceived service quality are noticeably weaker when the effect of SMT service climate is accounted for, which implies that the SMT climate mediates the relationships between antecedents and perceived service quality (see Baron and Kenny 1986). Compared with share of customer and sales productivity, the mediating role of SMT service climate is less obvious.

\section{Analysis}

To justify data aggregation, we examined tolerance for selfmanagement, flexibility of team members, inter- and intrateam support, and SMT service climate on withingroup agreement and interdependence. First, the average $\mathrm{r}_{\mathrm{WG}(\mathrm{j})}$ coefficients (ranging from .84 to .95 at T1 and at T2) are high for all variables and show high ratings consistency among employees within groups (James 1982). Second, the intraclass correlation (ICC) (1) coefficients (ranging from .06 to .18 at $\mathrm{T} 1$ and from .05 to .14 at $\mathrm{T} 2$ ) indicate that for all variables, a small to moderate part concerns betweengroup variance. To determine interdependence appropriately, it is also relevant to consider group size (Bliese 2000). Therefore, we calculated ICC (2) coefficients, because this measure of interdependence accounts for group size. Of the ICC (2) values, $90 \%$ are greater than .50 , which provides evidence for reliable group means and enables the detection of group-level relationships, even in the case of relatively small ICC (1) values (Bliese 2000).

We tested $\mathrm{H}_{1}-\mathrm{H}_{5}$ with employee data at $\mathrm{T} 1$ and estimated multilevel models using MLwiN software (Rasbash et al. 2000). We first included the control variables and the antecedents (Model A1). We then specified interactions between the dummy variable nonroutine services and the antecedents (Model A2). ${ }^{2}$ Model specification is provided in the Appendix.

To compare individual- and group-level effects of the antecedents on SMT service climate, we split the antecedent variables into the group mean and within-group deviation score (i.e., individual score - group mean). ${ }^{3}$ The coefficient of the group means reflects the group-level effect, whereas the coefficient of the within-group deviation scores reflects the individual-level effect (Bryk and Raudenbush 1992; Snijders and Bosker 1999). To interpret the coefficients appro-

\footnotetext{
${ }^{2}$ To control for multicollinearity, we inspected the variance inflation factors of the variables. The control variables and the antecedents yielded values less than 3.9 and 2.0, respectively, indicating the absence of serious multicollinearity problems (Kleinbaum, Kupper, and Muller 1988).

${ }^{3}$ Within-group deviation is similar to group mean-centering. In all analyses, we group mean-centered individual-level variables and grand mean-centered group-level variables to (1) distinguish within- and between-group variance, (2) reduce multicollinearity, and (3) facilitate model estimation (see Bryk and Raudenbush 1992).
}

priately, we needed to know whether the individual- and group-level coefficients were equal. First, when both coefficients are significant and equal, the variable functions principally at the individual level, and there is no separate main effect at the group level. Second, when only the individuallevel coefficient is significant and the group-level coefficient is not significant, the effect is solely based on social comparison within the group. Finally, when both the group- and the individual-level coefficients are significant but differ in magnitude, there is both an individual-level effect and an independent group-level effect (Van Yperen and Snijders 2000).

Table 5 contains the results of the multilevel analyses. There are positive individual-level effects of tolerance for self-management, flexibility, and inter- and intrateam support on the SMT service climate, in support of $\mathrm{H}_{1}-\mathrm{H}_{3}$. In addition, we tested the cross-level hypothesis $\left(\mathrm{H}_{4}\right)$. A comparison of the individual- and group-level coefficients shows that tolerance for self-management and flexibility have significant, positive group-level effects on the SMT service climate. However, these do not significantly differ from the individual-level effects. Thus, the results indicate no support for $\mathrm{H}_{4 \mathrm{a}}$ and $\mathrm{H}_{4 \mathrm{~b}}$. The group-level effect of interteam support is nonsignificant and significantly weaker than its individual-level counterpart. Therefore, $\mathrm{H}_{4 \mathrm{c}}$ is rejected. Only intrateam support shows a significant, positive grouplevel effect on SMT service climate that is significantly stronger than its individual-level effect, in support of $\mathrm{H}_{4 \mathrm{~d}}$.

With respect to the control variables, our findings show a significant, positive group-level effect of age on SMT service-climate perceptions that is significantly stronger than its individual-level counterpart. Similarly, we find a significant, negative group-level effect of organizational tenure on the outcome variable. At the same time, however, although the group-level predictors are highly positively correlated, each has a negligible correlation with the SMT service climate. Yet the inclusion of group-level tenure as a second predictor of the SMT service climate in addition to group-level age significantly increases the model fit $\left(\chi_{(1)}^{2}=\right.$ $5.68 ; p<.05)$ and results in significant effects of both predictors on the SMT service climate. In contrast, inclusion of age as a second predictor beyond tenure results in a better model fit $\left(\chi_{(1)}^{2}=5.56 ; p<.05\right)$ and significant effects for the two predictors. Therefore, it appears that both tenure and age can be considered suppressor variables that mutually suppress each other's irrelevant variance for the prediction of the SMT service climate. Essentially, suppressors partial out the variance in the predictor variable that is due to measurement artifacts (Hinkle, Wiersma, and Jurs 1994). Therefore, to determine the effects of tenure and age on SMT service climate adequately, it is necessary to include both variables in the model. Finally, the results show that nonroutine service tasks have a positive impact on climate perceptions.

In addition, we tested whether the relationships between antecedents and the SMT service climate differ across service settings by specifying interactions between nonroutine services and antecedents. The inclusion of the interaction terms does not significantly improve the fit of Model A2 compared with Model A1. We found one significant, posi- 
TABLE 4

Group-Level Means, Standard Deviations, and Correlations of Employee Variables and External Outcomes

\begin{tabular}{|c|c|c|c|c|c|c|c|c|c|c|c|c|c|c|c|c|}
\hline \multirow[b]{2}{*}{ Variables } & \multirow{2}{*}{\multicolumn{2}{|c|}{ Mean (s.d.) }} & \multicolumn{14}{|c|}{$N=61$} \\
\hline & & & 1 & 2 & 3 & 4 & 5 & 6 & 7 & 8 & 9 & 10 & 11 & 12 & 13 & 14 \\
\hline 1. Perceived service & & & & & & & & & & & & & & & & \\
\hline quality $_{\mathrm{T} 2}$ & 4.17 & $(.16)$ & - & & & & & .20 & .11 & -.02 & .07 & & -.07 & .14 & -.13 & -.05 \\
\hline 2. Share of customer ${ }_{\mathrm{T} 2}$ & 2.34 & $(.65)^{\mathrm{a}}$ & -.14 & - & & & & $-.23^{\star}$ & .08 & $.33^{* *}$ & $.30^{\star *}$ & & -.14 & -.14 & .14 & .19 \\
\hline 3. Sales productivity ${ }_{\mathrm{T} 2}$ & $525.73(477$ & $7.92)^{a}$ & $-.25^{\star}$ & $.63^{\star \star \star}$ & - & & & $-.33^{\star *}$ & .07 & .13 & .19 & & $-.26^{*}$ & -.05 & .11 & $.27^{\star *}$ \\
\hline $\begin{array}{l}\text { 4. Nonroutine services } \\
5 \text { SMT service }\end{array}$ & .59 & $(.50)$ & $.24^{*}$ & $-.69^{\star * \star}$ & $-.97^{\star \star \star}$ & - & & & & & & & & & & \\
\hline climate $_{\mathrm{T} 1}$ & 5.42 & $(.35)$ & $.40^{\star \star *}$ & .12 & -.21 & .13 & - & & & & & & & & & \\
\hline $\begin{array}{l}\text { 6. Iolerance tor } \\
\text { self-management }{ }_{\mathrm{T} 1} \\
\text { 7. Flexibility of }\end{array}$ & 5.52 & $(.43)$ & $.37^{\star \star \star}$ & -.12 & $-.38^{\star \star \star}$ & $.34^{\star \star \star}$ & $.56^{\star \star \star}$ & - & & & & & & & & \\
\hline members $_{\mathrm{T} 1}$ & 5.41 & $(.40)$ & $.28^{\star \star}$ & .13 & -.04 & -.04 & $.48^{\star \star \star}$ & $.25^{\star}$ & - & & & & & & & \\
\hline 8. Interteam support ${ }_{\mathrm{T} 1}$ & 4.44 & $(.48)$ & .02 & $.33^{* * *}$ & .11 & -.15 & .08 & .10 & .18 & - & & & & & & \\
\hline $\begin{array}{l}\text { 9. Intrateam support } \\
\text { 10. SMT service }\end{array}$ & 5.03 & $(.38)$ & $.30^{\star \star}$ & $.31^{\star \star}$ & .02 & -.10 & $.62^{\star * \star}$ & $.34^{\star * *}$ & $.53^{\star \star \star}$ & $.33^{\star \star}$ & - & & & & & \\
\hline $\begin{array}{l}\text { climate }_{\mathrm{T} 2} \\
\text { 11. Tolerance for }\end{array}$ & 5.44 & $(.35)$ & $.25^{\star}$ & -.11 & $-.32^{\star \star}$ & $.29^{\star \star}$ & $.63^{\star \star \star}$ & $.50^{\star \star \star}$ & $.42^{\star \star \star}$ & .07 & $.36^{\star \star \star}$ & - & & & & \\
\hline $\begin{array}{l}\text { self-management } \\
\text { 12. Flexibility of }\end{array}$ & 5.61 & $(.41)$ & .06 & -.18 & $-.37^{\star \star \star}$ & $.34^{* *}$ & $.32^{\star *}$ & $.62^{\star \star \star}$ & .16 & .06 & .14 & $.47^{\star \star \star}$ & - & & & \\
\hline members $_{\mathrm{T} 2}$ & 5.51 & $(.33)$ & $.23^{\star}$ & -.18 & -.19 & .16 & $.42^{\star \star \star}$ & $.36^{\star \star \star}$ & $.38^{\star \star \star}$ & -.08 & $.30^{\star \star}$ & $.46^{\star \star \star}$ & $.40^{\star \star *}$ & - & & \\
\hline 13. Interteam support $\mathrm{T}_{\mathrm{T} 2}$ & 4.54 & $(.50)$ & -.08 & .12 & .04 & -.04 & -.06 & .03 & .19 & $.57^{\star \star \star}$ & .20 & .19 & $.39^{\star \star *}$ & $.32^{\star \star}$ & - & \\
\hline 14. Intrateam support T2 $^{2}$ & 5.17 & $(.52)$ & .06 & .12 & .10 & -.11 & $.40^{\star \star \star}$ & .14 & .11 & .24 & $.36^{\star \star \star}$ & $.41^{\star \star \star}$ & $.32^{\star \star}$ & $.50^{\star \star \star}$ & $.40^{\star \star \star}$ & - \\
\hline
\end{tabular}

${ }^{*} p<.10$.

${ }^{* *} p<.05$.

${ }_{* \star *} p<.001$.

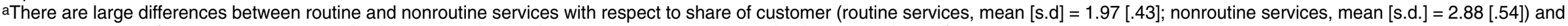
sales productivity (routine services, mean [s.d] = 1076.26 [171.32]; nonroutine services, mean [s.d] = 143.37 [67.77]).

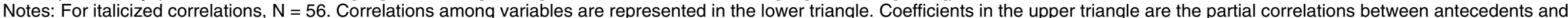
outcomes. For the partial correlations with antecedents at T1, we partialled out the effect of SMT service climate $\mathrm{T}_{1}$; for antecedents at T2, we partialled out the effect of SMT service climate T2 $_{2}$. 
TABLE 5

Results of the Multilevel Analyses

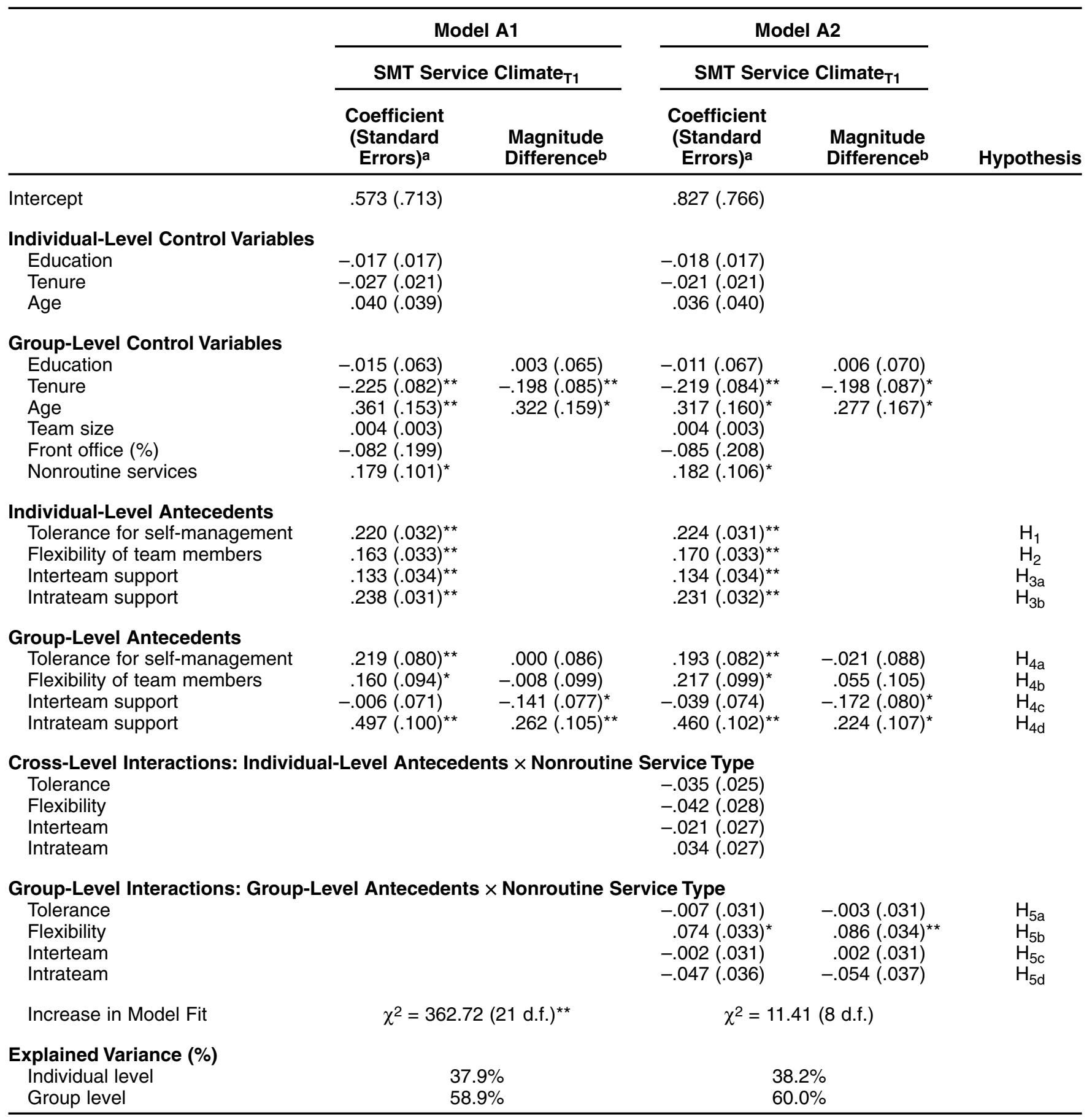

${ }^{*} p<.05$.

${ }^{* *} p<.01$.

aUnstandardized regression coefficients.

bWe tested differences in magnitude between individual- and group-level coefficients by means of raw-score analyses, and these are reflected in the presented group-level coefficients.

Notes: Significance is based on one-tailed tests.

tive interaction of nonroutine services $\times$ team member flexibility at the group level. The addition of this interaction term to the model leads to a significant increase in model fit $\left(\chi_{(1)}^{2}=5.92 ; p<.05\right)$, indicating support for $\mathrm{H}_{5 \mathrm{~b}}$. Specifically, the magnitude of this group-level interaction effect is significantly stronger than its individual-level counterpart.
The specified group-level interactions of nonroutine services with tolerance for self-management and inter- and intrateam support appear to be nonsignificant. This implies that there are no differences in group-level effects of the antecedents across service types. Thus, $\mathrm{H}_{5 \mathrm{a}}, \mathrm{H}_{5 \mathrm{c}}$, and $\mathrm{H}_{5 \mathrm{~d}}$ are rejected. Finally, the percentage of explained variance at the 
group level is higher than that at the individual level, indicating that between-group differences of SMT service climate are more effectively explained than within-group differences.

To substantiate our results, we performed additional analyses. The results of the analyses are presented in Table 6 . First, we conducted a lagged analysis and investigated the delayed effects of the antecedent variables at T1 on SMT service climate at T2 (Model B1). To control for an employee's previous evaluation of SMT service climate at T1, we included this variable as an additional predictor (see Bolton and Drew 1991). The reported estimates reveal a somewhat weaker but largely consistent pattern as compared with the cross-sectional analysis (Model A2). Specifically,

TABLE 6

Results of Additional Multilevel Analyses

\begin{tabular}{|c|c|c|c|c|}
\hline & \multirow{2}{*}{\multicolumn{2}{|c|}{$\begin{array}{c}\text { Model B1 (Lagged Analysis) } \\
\text { SMT Service Climate }_{\mathrm{T} 1}\end{array}$}} & \multirow{2}{*}{\multicolumn{2}{|c|}{$\begin{array}{c}\text { Model B2 (Gibbs Sampling)c } \\
\text { SMT Service Climate }_{\mathrm{T} 2} \\
\end{array}$}} \\
\hline & & & & \\
\hline & $\begin{array}{c}\text { Coefficient } \\
\text { (Standard Errors) }^{a}\end{array}$ & $\begin{array}{l}\text { Magnitude } \\
\text { Differenceb }^{b}\end{array}$ & $\begin{array}{c}\text { Coefficient } \\
\text { (Standard Errors) }^{a}\end{array}$ & $\begin{array}{l}\text { Magnitude } \\
\text { Differenceb }^{b}\end{array}$ \\
\hline $\begin{array}{l}\text { Intercept } \\
\text { SMT Service Climate }_{\mathrm{T} 1}\end{array}$ & $\begin{array}{r}-.255(.967) \\
.334(.051)^{\star \star}\end{array}$ & & $.842(.773)$ & \\
\hline $\begin{array}{l}\text { Individual-Level Control Variable } \\
\text { Education } \\
\text { Tenure } \\
\text { Age }\end{array}$ & $\begin{array}{r}-.001(.024) \\
.000(.030) \\
.141(.060)^{\star \star}\end{array}$ & & $\begin{array}{r}-.018(.017) \\
-.021(.021) \\
.035(.040)\end{array}$ & \\
\hline $\begin{array}{l}\text { Group-Level Control Variables } \\
\text { Education } \\
\text { Tenure } \\
\text { Age } \\
\text { Team size } \\
\text { Front office }(\%) \\
\text { Nonroutine services }\end{array}$ & $\begin{array}{r}-.064(.086) \\
-.189(.092)^{\star} \\
.496(.188)^{\star \star} \\
.004(.004) \\
-.308(.280) \\
.265(.145)^{\star}\end{array}$ & $\begin{array}{r}-.045(.094) \\
-.192(.102)^{\star} \\
.363(.207)^{\star}\end{array}$ & $\begin{aligned}-.012(.069) \\
-.219(.085)^{\star \star} \\
.316(.163)^{\star} \\
.004(.003) \\
-.088(.214) \\
.182(.107)^{\star}\end{aligned}$ & $\begin{array}{r}.006(.071) \\
-.196(.088)^{\star} \\
.278(.169)^{\star}\end{array}$ \\
\hline $\begin{array}{l}\text { Individual-Level Antecedents } \\
\text { Tolerance for self-management } \\
\text { Flexibility of team members } \\
\text { Interteam support } \\
\text { Intrateam support }\end{array}$ & $\begin{array}{l}.138(.058)^{\star \star} \\
.164(.073)^{\star} \\
.089(.049)^{\star} \\
.100(.051)^{\star}\end{array}$ & & $\begin{array}{l}.223(.032)^{\star \star} \\
.169(.034)^{\star \star} \\
.132(.031)^{\star \star} \\
.232(.031)^{\star \star}\end{array}$ & \\
\hline $\begin{array}{l}\text { Group-Level Antecedents } \\
\text { Tolerance for self-management } \\
\text { Flexibility of team members } \\
\text { Interteam support } \\
\text { Intrateam support }\end{array}$ & $\begin{array}{l}.183(.099)^{\star} \\
.121(.119) \\
.009(.087) \\
.335(.121)^{\star \star}\end{array}$ & $\begin{array}{r}.019(.118) \\
.040(.136) \\
-.076(.106) \\
.242(.138)^{\star}\end{array}$ & $\begin{array}{r}.194(.084)^{\star} \\
.214(.101)^{\star} \\
-.039(.075) \\
.459(.105)^{\star *}\end{array}$ & $\begin{array}{r}-.021(.090) \\
.064(.106) \\
-.168(.083)^{\star} \\
.214(.109)^{\star}\end{array}$ \\
\hline $\begin{array}{l}\text { Cross-Level Interactions: Individ } \\
\text { Tolerance } \\
\text { Flexibility } \\
\text { Interteam } \\
\text { Intrateam }\end{array}$ & $\begin{array}{r}\text {-evel Antecedents } \times \\
-.009(.038) \\
.052(.053) \\
.001(.037) \\
-.054(.039)\end{array}$ & 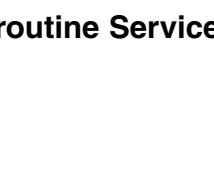 & $\begin{array}{r}-.035(.025) \\
-.041(.027) \\
-.023(.025) \\
.035(.027)\end{array}$ & \\
\hline $\begin{array}{l}\text { Group-Level Interactions:Group- } \\
\text { Tolerance } \\
\text { Flexibility } \\
\text { Interteam } \\
\text { Intrateam }\end{array}$ & $\begin{array}{c}\text { Antecedents } \times \text { No } \\
-.014(.046) \\
.078(.044)^{\star} \\
.066(.038)^{\star} \\
-.082(.052)\end{array}$ & $\begin{array}{l}\text { ine Service Typ } \\
-.003(.050) \\
.083(.048)^{\star} \\
.060(.041) \\
-.058(.057)\end{array}$ & $\begin{array}{l}-.007(.031) \\
.074(.033)^{*} \\
-.002(.032) \\
-.046(.037)\end{array}$ & $\begin{array}{r}-.002(.032) \\
.082(.034)^{\star \star} \\
.002(.032) \\
-.054(.038)\end{array}$ \\
\hline $\begin{array}{l}\text { Explained Variance (\%) } \\
\text { Individual level } \\
\text { Group level }\end{array}$ & $\begin{array}{l}42.3 \% \\
59.0 \%\end{array}$ & & $\begin{array}{l}37.7 \% \\
57.9 \%\end{array}$ & \\
\hline
\end{tabular}

${ }^{*} p<.05$.

${ }^{* *} p<.01$.

aUnstandardized regression coefficients.

bWe tested differences in magnitude between individual- and group-level coefficients by means of raw-score analyses, and these are reflected in the presented group-level coefficients.

cModel B2: Gibbs sampling (10,000 iterations).

Notes: Significance is based on one-tailed tests. 
these findings empirically demonstrate that the antecedents have a positive impact on the development of the SMT service climate over time. Second, to test the accuracy and stability of parameter estimates (Model B2), we conducted the simulation procedure using Gibbs sampling (Gilks, Richardson, and Spiegelhalter 1996). ${ }^{4}$ The parameter values we obtained through this simulation were fairly similar to the Model A2 estimates. Third, we performed the Chow $F_{c}$ test to determine whether there had been a structural change in the antecedent-SMT service climate relationships between $\mathrm{T} 1$ and $\mathrm{T} 2$. The Chow $\mathrm{F}_{\mathrm{c}}$ test reported no significant $\mathrm{F}$ value $\left(\mathrm{F}_{25,1435}=1.00 ; p=.46\right)$, which indicates that there were no structural alterations over time. Overall, this model validation indicates insensitivity of the results to various time frames and different estimation methods, and it confirms consistency in findings and provides additional support for their managerial relevance.

Subsequently, we investigated the effect of SMT service climate at $\mathrm{T} 1$ on several team outcomes at T2. To assess the linkage between SMT service climate and its consequences empirically, we aggregated employee and customer perceptions to the group level. It has been argued that customers primarily observe the outcome of integrative working relationships among multiple employees (Allen and Grisaffe 2001). Furthermore, outgroup-homogeneity theory postulates that people tend to perceive other groups as more uniform than their own group (Quattrone and Jones 1980). This means that whereas employees may have a relatively detailed view of their own team's performance, external customers are likely to generalize the quality of service offered by one or multiple team members as a common characteristic of a homogeneous out-group. Moreover, it was not possible to match empirically employee and customer evaluations and productivity criteria at the individual level of analysis.

We tested $\mathrm{H}_{6}-\mathrm{H}_{8}$ using a multivariate regression model formulated as a two-level hierarchical linear model. Level 1 refers to the dependent variables indexed by $h=1, \ldots, \mathrm{m}$, and Level 2 reflects the teams $\mathrm{j}=1, \ldots, \mathrm{N}$. Thus, each measurement of a dependent variable for some team is indicated by a separate line in the data matrix, which contains the values $\mathrm{j}, \mathrm{h}, \mathrm{Y}_{\mathrm{hj}}, \mathrm{x}_{1 \mathrm{j}}$ and those of other explanatory variables. To formulate the multivariate regression model as a hierarchical linear model, we used the dummy variables $d_{1}$ to $d_{m}$ to indicate the dependent variables (i.e., perceived service quality $_{\mathrm{T} 2}$, share of customer $\mathrm{T}_{\mathrm{T} 2}$, and sales productivity ${ }_{\mathrm{T} 2}$ ). Dummy variable $d_{h}$ is equal to one or zero, depending on whether the data line refers to the dependent variable $Y_{h}$ or to another dependent variable. With the dummy variables, the regression models for the $m$ dependent variables can be integrated into one two-level hierarchical model with the following expression:

\footnotetext{
${ }^{4}$ Gibbs sampling works by simulating a new value for each parameter from its conditional distribution and by assuming that the current values for the other parameters are the true values.
}

(1) $\mathrm{Y}_{\mathrm{hj}}=\sum_{\mathrm{s}=1}^{\mathrm{m}} \gamma_{0 \mathrm{~s}} \mathrm{~d}_{\mathrm{shj}}+\sum_{\mathrm{k}=1}^{\mathrm{p}} \sum_{\mathrm{s}=1}^{\mathrm{m}} \gamma_{\mathrm{ks}} \mathrm{d}_{\mathrm{shj}} \mathrm{x}_{\mathrm{kj}}+\sum_{\mathrm{s}=1}^{\mathrm{m}} \mathrm{e}_{\mathrm{sj}} \mathrm{d}_{\mathrm{shj}}$.

We multiplied all variables (including the constant) by the dummy variables. Note that in the sums over $\mathrm{s}=1, \ldots, \mathrm{m}$, only the term for $\mathrm{s}=\mathrm{h}$ renders a contribution; all other terms disappear. The following equation involves a simplified representation of Equation 1:

$$
\begin{gathered}
\mathrm{Y}_{\mathrm{hj}}=\gamma_{0 \mathrm{~h}}+\gamma_{1 \mathrm{~h}} \text { SERVCLIM }_{\mathrm{T} 1 \mathrm{j}}+\gamma_{2 \mathrm{~h}} \text { NROUT }_{\mathrm{j}}+ \\
\gamma_{3 \mathrm{~h}}\left(\text { SERVCLIM }_{\mathrm{T} 1 \mathrm{j}} \times \text { NROUT }_{\mathrm{j}}\right)_{\mathrm{j}}+\mathrm{e}_{\mathrm{hj}},
\end{gathered}
$$

where $Y_{h j}$ is the measurement on the hth variable for group $\mathrm{j}$, SERVCLIM $_{\mathrm{T} 1}$ is the team's SMT service-climate average at T1, and NROUT reflects the type of service.

Our results in Table 7 reveal significant, positive effects of SMT service climate ${ }_{\mathrm{T} 1}$ on perceived service quality $\mathrm{T}_{2}$ and share of customer $\mathrm{T}_{\mathrm{T} 2}$ and a significant, negative effect on sales productivity 2 . The findings support $\mathrm{H}_{6}$ and $\mathrm{H}_{7}$. Furthermore, the service-type dummy "nonroutine services" is positively related to customer perceived service quality but is negatively related to share of customer and sales productivity. In addition, we tested interactions between service type and the SMT service climate. There is a positive interaction effect of nonroutine services $\times$ SMT service climate on perceived service quality, but no significant interactions appear for share of customer and sales productivity. Thus, $\mathrm{H}_{8 \mathrm{a}}$ is supported, and $\mathrm{H}_{8 \mathrm{~b}}$ and $\mathrm{H}_{8 \mathrm{c}}$ are rejected.

\section{Discussion}

The key objective of our study was to analyze the chain of events between perceptions of boundary-spanning service employees organized in SMTs and critical marketing performance criteria. We developed the construct of SMT service climate and empirically demonstrated that it plays a pivotal role in the prediction of SMT performance dimensions. We have empirical verification that tolerance for selfmanagement, flexibility, and inter- and intrateam support have a direct, positive impact on individual employees' service-climate perceptions. In addition, we found that the group-level measure of intrateam support adds uniquely to the explanation of SMT service-climate perceptions. Moreover, we found that service type moderates the group-level effect of flexibility. Both effects persist over time, which nuances Mohammed, Mathieu, and Bartlett's (2002) general observation that perceptual agreement among team members with respect to interpersonally oriented behaviors is crucial to the performance of the team's core tasks. For boundary-spanning service delivery, shared perceptions of support and team flexibility are conducive to the creation of a climate related to the SMT's core task. Our results suggest that the dynamics of supportive behavior in the SMT's providing service to customers have crystallized into a coherent, collective perception and that beliefs of any team member are likely to be influenced by the attitudes and behavior of other members. This seems important because service delivery is heterogeneous across employees, and delivery of consistent service quality is a constant challenge. Further- 
Table 7

The Results of the SMT Service Climate-Outcome Relationships

\begin{tabular}{|c|c|c|c|c|c|}
\hline \multirow[b]{3}{*}{ 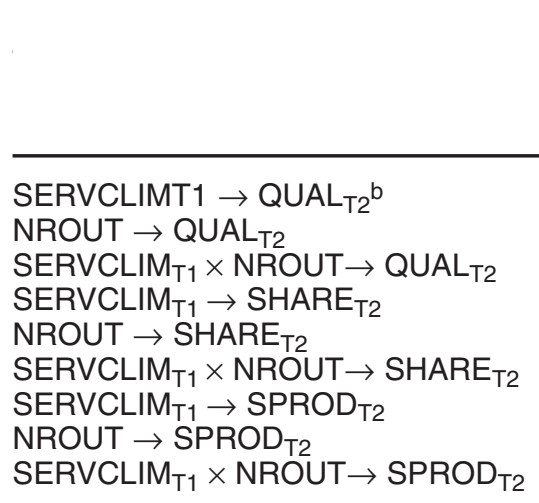 } & \multirow{2}{*}{\multicolumn{2}{|c|}{$\begin{array}{l}\text { Model C1 } \\
\text { Coefficient } \\
\text { tandard Errors)a }\end{array}$}} & \multirow{2}{*}{\multicolumn{2}{|c|}{$\begin{array}{c}\text { Model C2 } \\
\begin{array}{c}\text { Coefficient } \\
\text { tandard Errors)a }\end{array}\end{array}$}} & \multirow{2}{*}{$\frac{\text { Hypothesis }}{\mathrm{H}_{6 \mathrm{a}}}$} \\
\hline & & & & & \\
\hline & $\begin{array}{r}.941 \\
.501 \\
.275 \\
-.953 \\
-73.862 \\
-922.734\end{array}$ & $\begin{array}{l}(.308)^{\star \star} \\
(.313) \\
(.119)^{\star \star} \\
(.121)^{\star \star} \\
(30.076)^{\star \star} \\
(30.539)^{\star \star}\end{array}$ & $\begin{array}{r}.969 \\
.510 \\
.336 \\
.268 \\
-.955 \\
-.082 \\
-72.430 \\
-922.305 \\
16.811\end{array}$ & $\begin{array}{c}(.295)^{\star \star} \\
(.299)^{\star} \\
(.134)^{\star \star} \\
(.118)^{\star \star} \\
(.119)^{\star \star} \\
(.053) \\
(29.961)^{\star \star} \\
(30.403)^{\star \star} \\
(13.570)\end{array}$ & $\begin{array}{c}\mathrm{H}_{6 \mathrm{a}} \\
\mathrm{H}_{8 \mathrm{a}} \\
\mathrm{H}_{6 \mathrm{~b}} \\
\mathrm{H}_{8 \mathrm{~b}} \\
\mathrm{H}_{7} \\
\mathrm{H}_{8 \mathrm{c}}\end{array}$ \\
\hline $\begin{array}{l}\text { Residual Between-Groups Covarian } \\
\sigma_{\mathrm{h}}^{2}=\operatorname{var}\left(\mathrm{e}_{\mathrm{hj}}\right),(\mathrm{h}=1) \\
\sigma_{\mathrm{h}}^{2}=\operatorname{var}\left(\mathrm{e}_{\mathrm{hj}}\right),(\mathrm{h}=2) \\
\sigma_{\mathrm{h}}^{2}=\operatorname{var}\left(\mathrm{e}_{\mathrm{hj}}\right),(\mathrm{h}=3) \\
\sigma_{12}=\operatorname{cov}\left(\mathrm{e}_{1 \mathrm{j}}, \mathrm{e}_{2 \mathrm{j}}\right) \\
\sigma_{13}=\operatorname{cov}\left(\mathrm{e}_{1 \mathrm{j}}, \mathrm{e}_{3 \mathrm{j}}\right) \\
\sigma_{23}=\operatorname{cov}\left(\mathrm{e}_{2 \mathrm{j}}, \mathrm{e}_{3 \mathrm{j}}\right)\end{array}$ & $\begin{array}{r}1.417 \\
.211 \\
13,507.870 \\
-.041 \\
6.225 \\
-7.755\end{array}$ & $\begin{array}{r}(.256) \\
(.039) \\
440.253) \\
(.070) \\
(17.704) \\
(6.927)\end{array}$ & $\begin{array}{r}1.298 \\
.206 \\
13,385.760 \\
-.006 \\
-.871 \\
-6.144\end{array}$ & $\begin{array}{r}(.235) \\
(.037) \\
423.142) \\
(.066) \\
(16.872) \\
(6.773)\end{array}$ & \\
\hline $\begin{array}{l}\text { Increase in model fit:c } \\
\text { Increase in model fit:d }\end{array}$ & $\begin{array}{r}\chi^{2}=232 \\
\chi^{2}=1\end{array}$ & $\begin{array}{l}(6 \text { d.f. })^{\star \star} \\
(3 \text { d.f. })\end{array}$ & $\begin{array}{r}\chi^{2}=10 \\
\chi^{2}=.8\end{array}$ & $\begin{array}{l}(3 \text { d.f. })^{*} \\
(3 \text { d.f. })\end{array}$ & \\
\hline
\end{tabular}

${ }^{*} p<.05$.

${ }^{\star *} p<.01$.

aUnstandardized regression coefficients.

bAs we aggregated the scale of perceived service quality to the group level, we calculated $\left.\mathrm{r}_{W G(J)}\right)$, ICC (1)-, and ICC (2)- coefficients (respectively $.96, .04$, and .51 ) to determine within-group agreement and interdependence.

cIncrease in model fit with inclusion of the predictor variables.

dIncrease in model fit with inclusion of the covariance terms among the outcome variables.

Notes: Significance is based on one-tailed tests.

more, because nonroutine services are relatively more complex and require in-depth know-how, there is a greater need to integrate mechanisms and group-embedded expertise when addressing heterogeneous, unpredictable customer demands on the front line. The group-level interaction effect signifies that a collective understanding of one another's roles and shared beliefs about the capability to perform various roles are particularly important for service-climate perceptions in SMTs that deliver nonroutine services. This extends Druskat and Pescosolido's (2002) finding that in complex task conditions, there is a higher need for information exchange from manufacturing SMTs to the setting of nonroutine service delivery. In contrast, no additional crosslevel effects (i.e., beyond individual perceptions) were reported for tolerance for self-management and interteam support. This implies that boundary-spanning service employees' perceptions of the impact of climate-defining determinants are based primarily on personal cognitions and interpretations of the team environment rather than on a property of the team.

This study extends previous research by taking into account a comprehensive set of SMTs' marketing performance measures. Our results demonstrate that SMT serviceclimate perceptions have a positive impact on customer perceived service quality and share of customer and a negative effect on sales productivity. We also find that the positive effect of customer perceived quality is significantly stronger for nonroutine services than for routine services. Thus, the direct relationship between organizational service climate and perceived service quality in financial services reported by Schneider, White, and Paul (1998) holds at the team level, but the strength of the relationship seems to be contingent on the service type. Particularly in the delivery of nonroutine services, which is often aimed at fulfilling specific customer needs, a climate focusing on service excellence appears to provide added value from customers' perspectives. In contrast, the relatively high within-group variability of SMT service climate for the routine service setting may have weakened the relationship between SMT service climate and perceived service quality.

Although SMT service climate contributes to a higher share of customer, it is associated with lower sales productivity levels. These results and the low correlations between the effectiveness measures may indicate what has been labeled the "performance paradox," a phenomenon that has been encountered in previous studies on firm performance (Meyer and Gupta 1995) and team performance (Spreitzer, Cohen, and Ledford 1999). An SMT climate for service does not necessarily improve all aspects of frontline service performance. This confirms Anderson, Fornell, and Rust's (1997) contention that trade-offs between different performance parameters are particularly applicable to services, 
and it emphasizes the necessity to set off customer parameters against productivity parameters to create an optimal balance.

\section{Theoretical Implications}

Our study contributes to the theoretical literature on SMTs in four ways. First, our findings illustrate the relevance of the SMT service climate in explaining the divergent findings encountered in the SMT literature. Although service climate has been studied extensively at the organizational level, the concept has been virtually unexplored in relation to SMTs. We conducted our study in the context of financial consumer services. Further research should assess the generalizability of our findings to other service settings (e.g., technical support, business-to-business services). Although we unequivocally demonstrate the impact of service climate on important performance parameters, the body of work on this construct in the marketing and organizational behavior areas suggests that there is still much to be learned about the nature and scope of the SMT service climate as it relates to team performance. Following Schneider, Salvaggio, and Subirats (2002), we modeled within-team variability by taking the standard deviation of the SMT service climate as a measure of cohesiveness. Notably, significant, positive interaction effects of SMT service climate $\times$ SMT climate cohesiveness on customer perceived service quality and sales productivity emerged. These findings demonstrate the relevance of perceptual agreement on SMT climate as a moderator of the relationship between SMT service climate and the outcome variables. However, the effect of cohesiveness did not hold when we specified conditions for service type, possibly because of relatively strong differences in within-group variability between routine and nonroutine service delivery. Additional insight is needed into the contingencies that influence the relationship between SMT service climate and effective customer service.

Second, our research contributes to a better understanding of which factors shape a climate for service within boundary-spanning SMTs. Both team- and company-related characteristics influence team members' perceptions of the SMT service climate. Our set of predictor variables pertains predominantly to interpersonally oriented behaviors. In further research, the focus might be more on the impact of technical-administrative or task-related behavior in SMTs.

Third, our study advances the understanding of the impact of predictor-criterion relationships across levels of analysis. Although recent multilevel research has recognized the importance of comparing relationships across levels (Ostroff, Kinicki, and Clark 2002), studies have focused almost exclusively on methodological issues. Additional investigation is needed to address the underlying theoretical mechanisms that cause these differences. For example, our findings on interteam support suggest the relevance of considering distortions in employee perceptions during comparison of relationships across levels. The purpose of ratings, performance norms, and social dynamics may affect ratings of situational elements (Ostroff 1993). It makes a difference whether respondents evaluate their own team or other (rival) teams within the organization. In other words, the team members' various motives and interests influence their workplace evaluation. Thus, conceptual development is required on implicit and explicit processes among individual service employees, their colleagues, and the broader organizational context.

Fourth, our findings present a balanced perspective of service climate as a success factor related to SMTs. Although the growth and importance of SMTs has been studied, research has neglected how SMTs are related to important business-performance measures. The study empirically demonstrates that all benefits of this factor may not be realized simultaneously and that inherent trade-offs are made. The divergent effects of the SMT service climate on customers' perceived service quality and share of customer, rather than sales productivity, may motivate researchers to investigate complementary mediator variables that explain the performance paradox between customerand productivity-based measures. Future conceptual models need to include more productivity-oriented performance mediators (e.g., cost consciousness) that are related to SMTs' planning and control activities (Singh 2000).

\section{Managerial Implications}

Our findings suggest several managerial implications. Given the group-level impact of intrateam processes, competency development and measurement with regard to intrateam support and flexibility should be aligned at the team level. Team-level interventions that are effective in creating a collective sense of support in the team include group exercises aimed at consensus building on, for example, service delivery standards, joint problem identification and analysis of customer complaints, the provision of assistance to colleagues in dealing with customers, and groupware and shared databases that facilitate information exchange. In addition, performance assessments should be related to the team's collective capabilities in providing internal and external service. Cross-training programs that focus on the ability of specialist employees to promote interchangeable expertise within nonroutine SMTs may be offered. Particularly for teams delivering complex and extended services, group meetings should be devoted to increasing team members' understanding of one another's tasks through role-play exercises. Cases on handling complex customer requests may be used to demonstrate problem solving and decisionmaking skills.

Our findings show that it is important to create a context that is supportive to self-management on the firm's front line, one that goes beyond formally loosening the managerial reigns. Tolerance for self-management entails creating a sense of personal freedom and control with respect to, for example, meeting customer expectations (see Bowen and Lawler 1992). However, the authority to perform in the interest of the customer as a team should be accompanied by the knowledge and skills as well as the resources to analyze team performance data from a business perspective, because this is one of the essential self-managing responsibilities of the team. In addition to the dissemination of power, timely feedback and strategic information on, for example, the impact of SMT decisions on customer perceptions and com- 
pany profitability should be distributed and discussed within the team. Management should play a leading role in coaching SMTs in their role as empowered customer-company interfaces. This calls for active engagement in plenary discussions on the firm's service strategy; involvement in training programs for skills in problem solving and customercomplaint handling, process analysis techniques, and performance assessments; and embedding of the role of SMTs in the social structure of the organization. Support from other teams is also an important driver of serviceclimate perceptions. Interteam support may be encouraged through job-rotation schemes, cross-training between SMTs on customer issues, and joint customer visits. Kirkman and Rosen (2000) refer to an insurance company that uses socalled bridge teams that are responsible for facilitating the communication and cooperation between service teams. Because the impact of extrateam factors occurs predominantly at the individual level, managerial strategies need not focus exclusively on team-level interventions. Personalized training in conjunction with plenary meetings and internal media may be used to reach employees and to strengthen the impact of climate-shaping antecedents for teams of frontline service providers.

A potentially counterintuitive and important finding suggests that firms should be aware of the SMT service climate's potential to have an adverse effect on sales productivity. Thus, SMTs may need both a productivity and a service orientation if management expects them to affect different outcomes positively. If the costs of service operations need to be reduced (a likely reality today), SMTs need to be involved in developing efficiency improvements, such as designing "smarter" service-delivery routines or identifying opportunities for cross- or up-selling during service encounters. When there is a need to work simultaneously on multiple drivers of different performance parameters, the results may vary across service types. Moreover, it is unlikely that all desirable outcomes will manifest at the same time. Our findings confirm that the impact of SMT climate can be observed over an extended period of time and can provide evidence of the potential to incorporate time frames in diagnostic assessments of the effectiveness of SMTs.

\section{Appendix Model Specification}

The basic multilevel regression model (Model A2) consists of a Level 1 (individual-level) submodel that specifies the effects of the within-group deviation variables and a Level 2 (group-level) submodel that specifies the effects of grouplevel variables. The Level 1 submodel is expressed as follows:

$$
\begin{aligned}
& \text { (A1) } \text { SERVCLIM }_{\mathrm{ij}}=\beta_{0 \mathrm{j}}+\beta_{1 \mathrm{j}} \text { EDUC }_{\mathrm{ij}}+\beta_{2 \mathrm{j}} \text { TEN }_{\mathrm{ij}}+\beta_{3 \mathrm{j}} \text { AGE }_{\mathrm{ij}} \\
& +\beta_{4 \mathrm{j}} \text { TOL }_{\mathrm{ij}}+\beta_{5 \mathrm{j}} \text { FLEX }_{\mathrm{ij}}+\beta_{6 \mathrm{j}} \text { INTER }_{\mathrm{ij}}+\beta_{7 \mathrm{j}} \text { INTRA }_{\mathrm{ij}}+\mathrm{e}_{\mathrm{ij}} .
\end{aligned}
$$

The Level 2 submodel is expressed as follows:

$$
\text { (A2) } \begin{aligned}
\beta_{0 j}= & \gamma_{00}+\gamma_{01} \text { EDUC }_{j}+\gamma_{02} \text { TEN }_{j}+\gamma_{03} \text { AGE }_{j}+\gamma_{04} \text { SIZE }_{j} \\
& +\gamma_{05} \text { FRONT }_{j}+\gamma_{06} \text { NROUT }_{j}+\gamma_{07} \text { TOL }_{j}+\gamma_{08} \text { FLEX }_{j}
\end{aligned}
$$

$$
\begin{aligned}
& +\gamma_{09} \text { INTER }_{j}+\gamma_{010} \text { INTRA }_{j}+\gamma_{011}\left(\text { TOL }_{j} \times \text { NROUT }_{j}\right)_{j} \\
& +\gamma_{012}\left(\text { FLEX }_{j} \times \text { NROUT }_{j}\right)_{j}+\gamma_{013}\left(\text { INTER }_{j} \times \text { NROUT }_{j}\right)_{j} \\
& +\gamma_{014}\left(\operatorname{INTRA}_{j} \times \text { NROUT }_{j}\right)_{j}+u_{0 j}
\end{aligned}
$$

$$
\beta_{\mathrm{qj}}=\gamma_{\mathrm{q} 0}+\gamma_{\mathrm{q} 1} \mathrm{NROUT}_{\mathrm{j}}+\mathrm{u}_{\mathrm{qj}} \text { for } \mathrm{q}(=4, \ldots, 7) \text {, and }
$$

$$
\beta_{\mathrm{qj}}=\gamma_{\mathrm{q} 0} \text { for } \mathrm{q}(=1, \ldots, 3),
$$

where i denotes individuals; $\mathrm{j}$ indicates groups; SERVCLIM is employees' SMT service-climate appraisal; EDUC, TEN, and AGE refer to employees' education, tenure, and age, respectively; SIZE, FRONT, and NROUT are the size of the team, the percentage of front-office workers in the team, and type of service, respectively; and TOL, FLEX, INTER, and INTRA are tolerance for self-management, team member flexibility, interteam support, and intrateam support, respectively. Substitution of Equations A2-A4 in Equation A1 yields the following multilevel model:

$$
\begin{aligned}
& \text { SERVCLIM }_{\mathrm{ij}}=\gamma_{00}+\gamma_{10} \text { EDUC }_{\mathrm{ij}}+\gamma_{20} \mathrm{TEN}_{\mathrm{ij}} \\
& +\gamma_{30} \mathrm{AGE}_{\mathrm{ij}}+\gamma_{40} \mathrm{TOL}_{\mathrm{ij}}+\gamma_{50} \mathrm{FLEX}_{\mathrm{ij}} \\
& +\gamma_{60} \text { INTER }_{\mathrm{ij}}+\gamma_{70} \text { INTRA }_{\mathrm{ij}} \\
& +\gamma_{80}\left(\text { TOL }_{\mathrm{ij}} \times \text { NROUT }_{\mathrm{j}}\right)_{\mathrm{ij}} \\
& +\gamma_{90}\left(\text { FLEX }_{\mathrm{ij}} \times \text { NROUT }_{\mathrm{j}}\right)_{\mathrm{ij}} \\
& +\gamma_{100}\left(\text { INTER }_{\mathrm{ij}} \times \text { NROUT }_{\mathrm{j}}\right)_{\mathrm{ij}} \\
& +\gamma_{110}\left(\text { INTRA }_{\mathrm{ij}} \times \text { NROUT }_{\mathrm{j}}\right)_{\mathrm{ij}} \\
& +\gamma_{01} \mathrm{EDUC}_{\mathrm{j}}+\gamma_{02} \mathrm{TEN}_{\mathrm{j}}+\gamma_{03} \mathrm{AGE}_{\mathrm{j}} \\
& +\gamma_{04} \mathrm{SIZE}_{\mathrm{j}}+\gamma_{05} \mathrm{FRONT}_{\mathrm{j}} \\
& +\gamma_{06} \mathrm{NROUT}_{\mathrm{j}}+\gamma_{07} \mathrm{TOL}_{\mathrm{j}}+\gamma_{08} \mathrm{FLEX}_{\mathrm{j}} \\
& +\gamma_{09} \text { INTER }_{j}+\gamma_{010} \text { INTRA }_{j} \\
& +\gamma_{011}\left(\text { TOL }_{\mathrm{j}} \times \text { NROUT }_{\mathrm{j}}\right)_{\mathrm{j}} \\
& +\gamma_{012}\left(\text { FLEX }_{\mathrm{j}} \times \text { NROUT }_{\mathrm{j}}\right)_{\mathrm{j}} \\
& +\gamma_{013}\left(\text { INTER }_{\mathrm{j}} \times \text { NROUT }_{\mathrm{j}}\right)_{\mathrm{j}} \\
& +\gamma_{014}\left(\text { INTRA }_{\mathrm{j}} \times \text { NROUT }_{\mathrm{j}}\right)_{\mathrm{j}} \\
& +u_{0 j}+u_{1 j}+u_{2 j}+u_{3 j}+u_{4 j}+e_{i j} .
\end{aligned}
$$

The individual-level error term $e_{i j}$ is normally distributed with a mean of zero and variance of $\sigma^{2}$. The random effects $\mathrm{u}_{\mathrm{qj}}(\mathrm{q}=0,4,5,6,7)$ are multivariate normal distributed over teams with an expected value of zero and variance $\left(\mathrm{u}_{\mathrm{qj}}\right)=$ $\tau_{\mathrm{qq}}$. Finally, $\mathrm{u}_{\mathrm{qj}}$ is the unique deviation of group $\mathrm{j}$ from the overall effect on the intercept $\left(\beta_{0 j}\right)$ while accounting for the group-level predictor variables.

We specified the coefficients $\beta_{0 \mathrm{j}}, \beta_{4 \mathrm{j}}, \ldots, \beta_{7 \mathrm{j}}$ as random coefficients (i.e., we allowed them to vary across groups). We constrained the predictor variables $\beta_{1 \mathrm{j}}, \beta_{2 \mathrm{j}}$, and $\beta_{3 \mathrm{j}}$ to be invariable across groups (i.e., we included no random term on Level 2 for these coefficients). In theory, we could specify all $\beta_{\mathrm{qj}}$ 's as random effects; however, statistically, such a model is not recommended, because it impedes model convergence and results in unstable parameter estimates (Bryk and Raudenbush 1992). 


\section{REFERENCES}

Allen, Nathalie J. and Douglas B. Grisaffe (2001), "Employee Commitment to the Organization and Customer Reactions: Mapping the Linkages," Human Resource Management Review, 11 (3), 209-236.

Anderson, Eugene W., Claes Fornell, and Roland T. Rust (1997), "Customer Satisfaction, Productivity, and Profitability: Differences Between Goods and Services," Marketing Science, 16 (2), 129-45.

Babin, Barry J. and Jill A. Attaway (2000), "Atmospheric Affect as a Tool for Creating Value and Gaining Share of Customer," Journal of Business Research, 49 (2), 91-99.

Balkema, Ageeth and Eric Molleman (1999), "Barriers to the Development of Self-Organizing Teams," Journal of Managerial Psychology, 14 (1-2), 230-43.

Baron, Reuben M. and David A. Kenny (1986), "The ModeratorMediator Variable Distinction in Social Psychological Research: Conceptual, Strategic, and Statistical Considerations," Journal of Personality and Social Psychology, 51 (6), 1173-82.

Batt, Rosemary (1999), "Work Organization, Technology, and Performance in Customer Service and Sales," Industrial and Labor Relations Review, 52 (4), 539-63.

(2002), "Managing Customer Services: Human Resource Practices, Quit Rates, and Sales Growth," Academy of Management Journal, 45 (3), 587-97.

Bernhardt, Kenneth L., Naveen Donthu, and Pamela A. Kennett (2000), "A Longitudinal Analysis of Satisfaction and Profitability," Journal of Business Research, 47 (2), 161-71.

Berry, Leonard L., A. Parasuraman, and Valarie Zeithaml (1994), "Improving Service Quality in America: Lessons Learned," Academy of Management Executive, 8 (2), 32-45.

Bettencourt, Lance A. and Stephen W. Brown (1997), "Contact Employees: Relationships Among Workplace Fairness, Job Satisfaction, and Prosocial Service Behaviors," Journal of Retailing, 73 (1), 39-61.

Blau, Gary (1995), "Influence of Group Lateness on Individual Lateness: A Cross-Level Examination," Academy of Management Journal, 38 (5), 1483-96.

Bliese, Paul D. (2000), "Within-Group Agreement, NonIndependence, and Reliability: Implications for Data Aggregation and Analysis," in Multilevel Theory, Research, and Methods in Organizations, Katherine J. Klein and Stephen W.J. Kozlowsik, eds. San Francisco: Jossey-Bass, 349-81.

Bolton, Ruth N. and James H. Drew (1991), "A Longitudinal Analysis of the Impact of Service Changes on Customer Attitudes," Journal of Marketing, 55 (January), 1-9.

Bowen, David E. and Edward E. Lawler III (1992), "The Empowerment of Service Workers: What, Why, How, and When?" Sloan Management Review, 33 (3), 31-39.

Brislin, Richard W. (1980), "Translation and Content Analysis of Oral and Written Materials," in Handbook of Cross-Cultural Psychology, Vol. 2, Harry C. Triandis and John W. Berry, eds. Boston: Allyn \& Bacon, 389-444.

Brown, Steven P. and Thomas W. Leigh (1996), "A New Look at Psychological Climate and Its Relationship to Job Involvement, Effort, and Performance," Journal of Applied Psychology, 81 (4), 358-68.

Bryk, Anthony S. and Stephen W. Raudenbush (1992), Hierarchical Linear Models: Applications and Data Analysis Methods. Newbury Park, CA: Sage Publications.

Cameron, Marsha and Jack Boise (1995), "Linking Rewards to Service: The Welch's Case," Journal of Compensation \& Benefits, 11 (2), 60-64.

Campion, Michael A., Gina J. Medsker, and Catherine A. Higgs (1993), "Relations Between Work Group Characteristics and
Effectiveness: Implications for Designing Effective Work Teams," Personnel Psychology, 46 (4), 823-50.

Chan, David (1998), "Functional Relations Among Constructs in the Same Content Domain at Different Levels of Analysis: A Typology of Composition Models," Journal of Applied Psychology, 83 (2), 234-46.

Chaston, Ian (1998), "Self-Managed Teams: Assessing the Benefits for Small Service-Sector Firms," British Journal of Management, 9 (1), 1-12.

Cohen, Susan G., Lei Chang, and Gerald E. Ledford Jr. (1997), “A Hierarchical Construct of Self-Management Leadership and Its Relationship to Quality of Work Life and Perceived Work Group Effectiveness," Personnel Psychology, 50 (2), 275-308.

Cook, Justine D., Stephen J. Hepworth, Toby D. Wall, and Peter B. Warr (1981), The Experience of Work: A Compendium and Review of 249 Measures and Their Use. London: Academic Press.

Davis, Tim R.V. (1999), "Different Service Firms, Different Core Competencies," Business Horizons, 42 (5), 23-34.

Druskat, Vanessa U. and Anthony T. Pescosolido (2002), "The Content of Effective Teamwork Mental Models in SelfManaging Teams: Ownership, Learning, and Heedful Interrelating," Human Relations, 55 (3), 283-314.

Gilks, Walter, Sylvia Richardson, and David J. Spiegelhalter (1996), Markov Chain Monte Carlo in Practice. London: Chapman and Hall.

Gilson, Lucy L., Christina E. Shalley, and Terry C. Blum (2001), "Team and Organizational Attitudes as a Lens and Mirror Impacting Customer Satisfaction: An Empirical Test in SelfManaged Teams," Journal of Quality Management, 6 (2), 235-56.

Griffin, Ricky (1991), "Effects of Work Redesign on Employee Perceptions, Attitudes, and Behaviors: A Long-Term Investigation," Academy of Management Journal, 32 (2), 425-35.

Gully, Stanley M., Aparna Joshi, Kara A. Incalcaterra, and J. Mattew Beaubien (2002), "A Meta-Analysis of Team-Efficacy, Potency, and Performance: Interdependence and Level of Analysis as Moderators of Observed Relationships," Journal of Applied Psychology, 87 (5), 819-32.

Hackman, J. Richard (1987), "The Design of Work Teams," in Handbook of Organizational Behavior, Jay W. Lorsch, ed. Englewood Cliffs, NJ: Prentice Hall, 315-42.

- (1992), "Group Influences on Individuals in Organizations," in Handbook of Industrial \& Organizational Psychology, Marvin D. Dunnette and Leaetta M. Hough, eds. Palo Alto, CA: Consulting Psychologists Press, 199-267.

Hartline, Michael D. and O.C. Ferrell (1996), "The Management of Customer-Contact Service Employees: An Empirical Investigation," Journal of Marketing, 60 (October), 52-70.

Hinkle, Dennis E., William Wiersma, and Stephen. G. Jurs (1994), Applied Statistics for the Behavioral Sciences. Boston: Houghton Mifflin.

Horwitz, Frank and Mark A. Neville (1996), "Organization Design for Service Excellence: A Review of the Literature," Human Resource Management, 35 (4), 471-92.

James, Lawrence R. (1982), "Aggregation Bias in Estimates of Perceptual Agreement," Journal of Applied Psychology, 67 (2), 219-29.

James, Lois A. and Lawrence R. James (1989), “Integrating Work Environment Perceptions: Explorations into the Measurement of Meaning," Journal of Applied Psychology, 74 (5), 739-51.

Katz, Daniel and Robert L. Kahn (1978), The Social Psychology of Organizations. New York: John Wiley \& Sons.

Kirkman, Bradley L. and Benson Rosen (2000), "Powering up Teams," Organizational Dynamics, 28 (3), 48-65. 
Kleinbaum, David G., Lawrence L. Kupper, and Keith E. Muller (1988), Applied Regression Analysis and Other Multivariable Methods. Boston: PWS-Kent.

Liang, Diane, Dick W. Moreland, and Linda Argote (1995), "Group Vs. Individual Training and Group Performance: The Mediating Role of Transactive Memory," Personality and Social Psychology Bulletin, 21 (4), 384-93.

Lindell, Michael K. and Christina J. Brandt (2000), "Climate Quality and Climate Consensus as Mediators of the Relationship Between Organizational Antecedents and Outcomes," Journal of Applied Psychology, 85 (3), 331-48.

Marks, Michelle A., C. Shawn Burke, Mark J. Sabella, and Stephen J. Zaccaro (2002), "The Impact of Cross-Training on Team Effectiveness," Journal of Applied Psychology, 87 (1), 3-13.

— John E. Mathieu, and Stephen J. Zaccaro (2001), "A Conceptual Framework and Taxonomy of Team Processes," Academy of Management Review, 26 (3), 356-76.

Mathieu, John E., Tonia S. Heffner, Gerald F. Goodwin, Eduardo Salas, and Janis A. Cannon-Bowers (2000), "The Influence of Shared Mental Models on Team Process and Effectiveness," Journal of Applied Psychology, 85 (2), 273-83.

and Stacey Kohler (1990), "A Cross-Level Examination of Group Absence Influence on Individual Absence," Journal of Applied Psychology, 75 (2), 217-20.

Meyer, Marshall W. and Vipin Gupta (1995), "The Performance Paradox," Research in Organizational Behavior, 16 (3), 309-369.

Mohammed, Susan, John E. Mathieu, and A.L. "Bart" Bartlett (2002), "Technical-Administrative Task Performance, Leadership Performance, and Contextual Performance: Considering the Influence of Team- and Task-Related Composition Variables," Journal of Organizational Behavior, 23 (7), 795-814.

Nunnally, Jum C. and Ira H. Bernstein (1994), Psychometric Theory, 3d ed. New York: McGraw-Hill

Ostroff, Cheri (1993), "Rater Perceptions, Satisfaction and Performance Ratings," Journal of Occupational and Organizational Psychology, 66 (4), 345-56.

— Angelo J. Kinicki, and Mark A. Clark (2002), "Substantive and Operational Issues of Response Bias Across Levels of Analysis: An Example of Climate-Satisfaction Relationship," Journal of Applied Psychology, 87 (2), 355-68.

Parasuraman, A., Valarie A. Zeithaml, and Leonard L. Berry (1988), "SERVQUAL: A Multiple-Item Scale for Measuring Consumer Perceptions of Service Quality," Journal of Retailing, 64 (1), 12-40.

Peccei, Riccardo and Patrice Rosenthal (1997), "The Antecedents of Employee Commitment to Customer Service: Evidence from a UK Service Context," The International Journal of Human Resource Management, 8 (1), 66-86.

Poole, Marshall S. and Robert D. McPhee (1983), "A Structurational Analysis of Organizational Climate," in Communication and Organizations: An Interpretive Approach, Linda L. Putnam and Michael E. Pacanowsky, eds. Beverly Hills, CA: Sage Publications, 195-219.

Quattrone, George A. and Ervin E. Jones (1980), "The Perception of Variability Within In-Groups and Out-Groups: Implications for the Law of Small Numbers," Journal of Personality and Social Psychology, 38 (1), 141-52.

Rasbash, Jon, William Browne, Harvey Goldstein, Min Yang, Ian Plewis, Michael Healy, Geoff Woodhouse, David Draper, Ian Langford, and Toby Lewis (2000), A User's Guide to MlwiN. London: Multilevel Models Project Institute of Education, University of London.
Schneider, Benjamin, Steven D. Ashworth, Andrew Higgs, and Linda Carr (1996), "Design, Validity, and Use of Strategically Focused Employee Attitude Surveys," Personnel Psychology, 49 (3), 695-705.

- and David E. Bowen (1985), "Employee and Customer Perceptions of Service in Banks: Replication and Extension," Journal of Applied Psychology, 70 (3), 423-33.

—, Amy Nicole Salvaggio, and Montse Subirats (2002), "Climate Strength: A New Direction for Climate Research," Journal of Applied Psychology, 87 (2), 220-29.

_, Jill K. Wheeler, and Jonathan F. Cox (1992), "A Passion for Service: Using Content Analysis to Explicate Service Climate Themes," Journal of Applied Psychology, 77 (5), 705-716.

— Susan S. White, and Michelle C. Paul (1998), "Linking Service Climate and Customer Perceptions to Service Quality: Test of a Causal Model," Journal of Applied Psychology, 83 (2), 150-63.

Singh, Jagdip (2000), "Performance Productivity and Quality of Frontline Employees in Service Organizations," Journal of Marketing, 64 (April), 15-34.

Snijders, Tom A.B. and Roel J. Bosker (1999), Multilevel Analysis: An Introduction to Basic and Advanced Multilevel Modeling. London: Sage Publications.

Soteriou, Andreas and Stavros A. Zenios (1999), "Operations, Quality, and Profitability in the Provision of Banking Services," Management Science, 45 (9), 1221-38.

Spreitzer, Gretchen M., Susan G. Cohen, and Gerald E. Ledford Jr. (1999), "Developing Self-Managing Work Teams in Service Organizations," Group \& Organization Management, 24 (3), 340-66.

Stewart, Greg L. and Murray R. Barrick (2000), "Team Structure and Performance: Assessing the Mediating Role of Intrateam Process and the Moderating Role of Task Type," Academy of Management Journal, 43 (2), 135-48.

Sundstrom, Eric, Kenneth P. de Meuse, and David Futrell (1990), "Work Teams: Applications and Effectiveness," American Psychologist, 45 (2), 120-33.

Tesluk, Paul E., James L. Farr, John E. Mathieu, and Robert J. Vance (1995), "Generalization of Employee Involvement Training to the Job Setting: Individual and Situational Effects," Personnel Psychology, 48 (3), 607-632.

Van Mierlo, Heleen, Christel G. Rutte, Brend Seinen, and Michiel Kompier (2001), "Autonomous Teamwork and Psychological Well-Being," European Journal of Work and Organizational Psychology, 10 (3), 291-301.

Van Yperen, Nico W. and Tom A.B. Snijders (2000), "A Multi-level Analysis of the Demands-Control Model: Is Stress at Work Determined by Factors at the Group Level or the Individual Level?" Journal of Occupational Health Psychology, 5 (1), 182-90.

Wageman, Ruth (1995), "Interdependence and Group Effectiveness," Administrative Science Quarterly, 40 (1), 145-80. - (1997), "Case Study: Critical Success Factors for Creating Superb Self-Managing Teams at Xerox," Compensation and Benefits Review, 29 (5), 31-41.

Yeatts, Dale E. and Cloyd C. Hyten (1998), High-Performing SelfManaged Teams: A Comparison of Theory to Practice. Thousand Oaks, CA: Sage Publications.

Zemke, Ron (1993), "Rethink the Rush to Team up," Training, 30 (11), 55-61. 
Copyright of Journal of Marketing is the property of American Marketing Association and its content may not be copied or emailed to multiple sites or posted to a listserv without the copyright holder's express written permission. However, users may print, download, or email articles for individual use. 